RODRIGO BENTO DE ANDRADE

\title{
O EFEITO DO LAPSO TEMPORAL E DO CONTROLE EXTERNO DOS TRIBUNAIS DE CONTAS NAS DECISÕES ADMINISTRATIVAS
}


RODRIGO BENTO DE ANDRADE

\title{
O EFEITO DO LAPSO TEMPORAL E DO CONTROLE EXTERNO DOS TRIBUNAIS DE CONTAS NAS DECISÕES ADMINISTRATIVAS
}

\author{
Monografia apresentada como requisito \\ para conclusão da disciplina TCC III do \\ curso de Bacharelado em Direito da \\ Faculdade Processus.
}

Orientador: Prof. Marco Aurélio de Souza 


\section{RESUMO}

A presente monografia tem como alvo discorrer sobre os efeitos do largo passar do tempo sobre as decisões administrativas, correlacionando-os com a atividade constitucional de controle externo exercida pelos tribunais de contas brasileiros. Logo de início, analisa-se os principais institutos do Direito relacionados com o lapso temporal, iniciando o estudo pela preclusão administrativa, então vinculada ao tempestivo agir das partes no campo processual. Após, busca-se enfrentar a prescrição, socorrendo-se primeiramente dos conceitos doutrinários do Direito Civil sobre o tema, para tão somente depois buscar as opiniões doutrinárias e as normas existentes no campo do Direito Administrativo. A seguir, exibe-se o conceito de decadência administrativa, bem como seus impactos nas decisões que foram ou que ainda devem ser tomadas pelo gestor da Administração. Por último, o presente trabalho é concluído ao revelar as implicações do decorrer do tempo no ato complexo de registro de aposentadorias por parte dos tribunais de contas, propondo ao final uma estreita relação entre a atividade de controle externo das cortes de contas e a atividade administrativa decisória.

PALAVRAS-CHAVE: Aposentadoria. Decadência. Prescrição. Controle Externo. Tribunais de Contas. 


\begin{abstract}
This monograph aims to discuss the effects of the long passage of time on administrative decisions, correlating them with the constitutional activity of external control exercised by the Brazilian court of accounts. From the outset, the main institutes of Law related to the temporal period are analyzed, starting the study by administrative preclusion, then linked to the timely action of the parties in the procedural field. Afterwards, it is sought to face the prescription, first resorting to the doctrinal concepts of Civil Law on the subject, only after to seek the doctrinal opinions and the existing norms in the field of Administrative Law. The following is the concept of administrative decay, as well as its impact on the decisions that have been or still must be taken by the Administration's manager. Finally, the present study reveals the implications of the passage of time in the complex act of registration of pensions by the courts of accounts, proposing at the end a close relationship between the activity of external control of the accounts and administrative activity decision-making.
\end{abstract}

KEYWORDS: Retirement. Decadence. Prescription. External Control. Courts of Accounts. 


\section{SUMÁRIO}

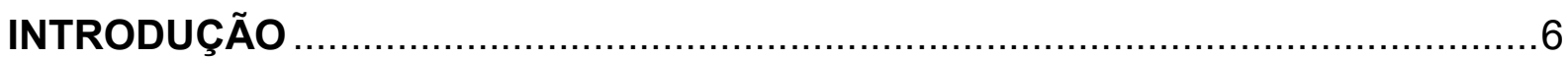

CAPÍTULO 1: PRECLUSÃO NO PROCESSO ADMINISTRATIVO …......................

1.1 Princípios referentes à preclusão no processo administrativo ................9

1.2 A preclusão e a sua previsão nas leis brasileiras de processo administrativo ...................................................................................... 16

1.2.1 Características da preclusão administrativa.......................................16

1.2.2 As leis brasileiras e a preclusão administrativa......................................19

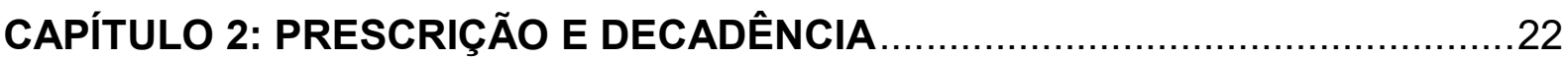

2.1 Efeitos da prescrição e decadência no processo administrativo .............22

2.1.1 Aspectos básicos da prescrição e decadência no código civil, e os seus

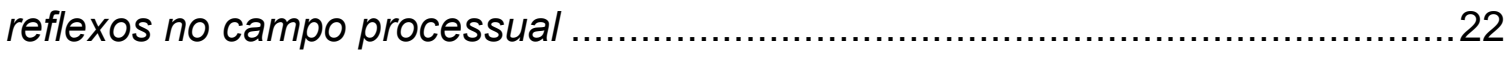

2.1.2 Características da prescrição no direito administrativo .............................28

2.1.3 Características da decadência no direito administrativo ..........................33

CAPÍTULO 3: A ALTERAÇÃO DA DECISÃO ADMINISTRATIVA EM FACE DO TRANSCURSO DE LARGO LAPSO TEMPORAL ......................................40

3.1 Coisa julgada administrativa ................................................................

3.2 Análise jurisprudencial quanto à coisa julgada administrativa ................44

3.3 O Controle das ddecisões aadministrativas pelos tribunais de contas ...47

3.3.1 Disposições constitucionais sobre os tribunais de contas.........................47

3.3.2 A coisa julgada administrativa e os tribunais de contas ............................50

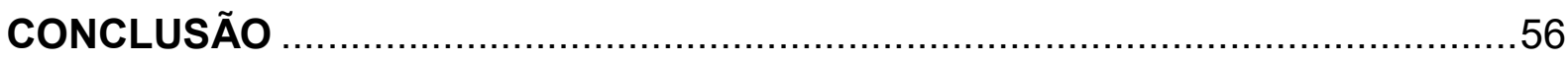

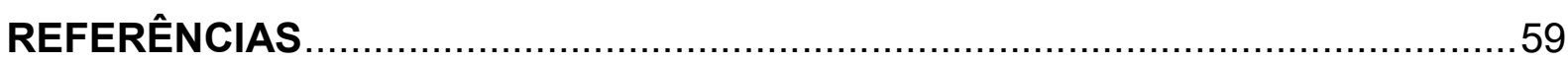




\section{INTRODUÇÃO}

O presente trabalho abordará a possibilidade de se alterar decisões administrativas, em face do poder constitucional de controle externo exercido pelos Tribunais de Contas, tendo como objetivo principal dissertar sobre a estabilidade de tais decisões, em face de situações fáticas que envolvem elementos de curso temporal ou de direito material e formal.

Sob esse ângulo, será realizada uma abordagem sob os principais aspectos que emergem da possibilidade de se modificar uma decisão no âmbito administrativo, demonstrando ainda as situações que a tornam estável, no que diz respeito às parcelas remuneratórias ou vantagens pecuniárias adquiridas pelo servidor público, contrapondo-as com a apreciação de atos complexos por parte dos Tribunais de Contas, mais especificamente o ato de aposentadoria.

Desse modo, serão discorridos na presente pesquisa os institutos da prescrição, da decadência, e da prescrição do fundo de direito, que podem conduzir à imutabilidade de uma decisão administrativa, inviabilizando o oferecimento de pedidos iniciais ou até mesmo a interposição de recursos por parte do interessado, bem como impossibilitando a modificação da decisão pela Administração.

Observe-se então que o foco do trabalho é avaliar se, após o transcurso de certo período, ou depois de surgir determinado evento de direito material/formal, uma decisão específica que concedeu alguma vantagem ao agente público poderá alcançar a estabilidade, considerando ainda que, no futuro, esse ato específico poderá ser revisto pelo Tribunal de Contas, quando da apreciação do ato de aposentadoria do servidor, ou até mesmo durante uma inspeção ou auditoria.

Saliente-se que o presente assunto é assaz relevante, posto que faz parte do dia-a-dia do gestor, que por diversas vezes, diante de uma revisão de ofício ou até mesmo atendendo a determinações de auditoria interna ou externa, depara-se com situações em que se sente inseguro para tomar decisões em um processo administrativo, posto que o longo correr do tempo levanta a possibilidade de existir um verdadeiro manto a cobrir a prestação jurisdicional administrativa anterior.

Destarte, será apresentado um estudo sobre as distintas nuances que envolvem a permanência de um julgado administrativo, correlacionando aspectos 
doutrinários e jurisprudenciais com princípios e corolários que orientam a Administração Pública brasileira, em face da análise futura dessas mesmas decisões por parte dos Tribunais de Contas em sua missão de Controle Externo, ao examinarem o ato complexo da aposentadoria, ou mesmo no correr de um processo de auditoria, estando o servidor ainda em atividade.

A problemática específica que abrange a modificação da decisão administrativa será discorrida durante o desenvolvimento dos capítulos, apresentando os principais problemas que são levados aos gestores públicos, ou identificados por eles, sobretudo no que diz respeito aos pedidos dos servidores que envolvem vantagens pecuniárias, bem como quando a própria Administração Pública identifica um erro na concessão de parcelas e deseja reformá-las de ofício, correlacionando essa problemática com o efeito do elemento temporal e o alcance dessas mesmas decisões pelo controle externo, de competência dos Tribunais de Contas.

Não são raras as vezes em que o servidor, após passados os cinco anos da já tão conhecida decadência ou prescrição quinquenal, peticiona junto à Administração, pleiteando alguma vantagem ou parcela de caráter pecuniário, requerendo assim a análise minuciosa do gestor, visando aplicar de forma escorreita a legislação ou a jurisprudência ao caso concreto.

De outra banda, ocorre ainda, nas mais diversas ocasiões, situações fáticas em que o administrador público identifica um erro contido em determinada decisão administrativa, que, à época, fez originar uma vantagem pecuniária indevida ao servidor.

No entanto, caso tenham se passados vários anos da publicação do referido ato ilegal, depara-se novamente o gestor com a possibilidade de ter transcorrido o prazo decadencial ou prescricional legal, fato que pode conferir a essa decisão a um status de imutabilidade.

Aqui reside o cerne do tema a ser trabalhado nos capítulos do presente trabalho, que consiste principalmente na avaliação sistemática, técnica e jurídica das ocasiões em que a decisão administrativa poderá ainda ser alterada, sopesando os princípios do interesse público e da segurança jurídica, e, também, buscando correlacionar o poder atribuído ao administrador para tal modificação e aquele conferido aos Tribunais de Contas em sua missão de extrato constitucional.

Ressalte-se que, durante a exposição da matéria no decorrer dessa pesquisa, serão colacionadas as jurisprudências atualmente utilizadas pelos Tribunais 
para solucionarem os casos concretos, bem como o pensamento doutrinário sobre os institutos da prescrição e da decadência em face de uma decisão administrativa.

Ademais, será levantado o instigante debate sobre a ponderação de princípios constitucionais, de Direito Público e de Direito Administrativo, em face de situações em que a simples letra da norma não é suficiente para resolver o caso concreto.

O método a ser utilizado no presente trabalho será predominantemente o dedutivo, posto que serão apresentados e enumeradas situações fáticas, bem como as principais teorias jurídicas sobre o assunto, possibilitando ao final produzir uma conclusão jurídica acerca dos principais elementos que envolvem o tema. 


\section{CAPÍTULO 1: PRECLUSÃO NO PROCESSO ADMINISTRATIVO}

Esse capítulo terá a preclusão administrativa como assunto, onde será dissertado sobre as suas principais características, explicando inicialmente que ela ocorre diante da inércia ou intempestividade de alguma das partes, que deixa de exercer em determinado momento uma faculdade processual.

Assim, após a devida explicação conceitual, serão abordados ainda os princípios que regem a sua aplicação, destacando os seus efeitos sobre os litigantes no processo, buscando aclarar principalmente que, caso determinado ato dentro do processo administrativo deixe de ser executado pelas partes no devido tempo legal, não mais assistirá a elas o direito de movimentar a máquina administrativa para aquela finalidade, seja por meio de um pedido inicial ou por meio de um recurso.

Ao final, será trabalhado a abordagem normativa da preclusão administrativa, com destaque para as previsões legais que existem no nosso ordenamento jurídico, que estão em regra relacionadas ao processo administrativo em si, conduzindo à conclusão de que a preclusão administrativa é o resultado do não exercício de uma pretensão por meio de uma ação em determinado limite de tempo, sendo que a mesma não advém de um direito material, mas sim tem como origem o resultado processual do não exercício de um direito.

\subsection{Princípios referentes à preclusão no processo administrativo}

O Processo Administrativo é um mecanismo de garantia que possuem os administrados, perante a outros administrados e ao próprio Estado. ${ }^{1}$

Dessa maneira, ao buscar o escorreito processamento dos feitos no decorrer da tramitação do processo junto à Administração, observando sempre os princípios constitucionais e de direito processual, proporciona-se ao administrado um verdadeiro escudo contra possíveis irregularidades e abusos de poder.

Nesse sentido, relevante destacar o juízo do professor José dos Santos Carvalho Filho, ao afirmar que "o processo é um mecanismo próprio para

1 FERRAZ, Sérgio; DALLARI, Adilson Abreu. Processo administrativo. 3. ed. São Paulo: Malheiros Editores, 2012, p. 31. 
dirimir os conflitos de interesses pela atuação efetiva do órgão jurisdicional, representante do Estado-Juiz". ${ }^{2}$

Então, ao final do processo, com todos os atos que o compõem, o cidadão titular de um direito subjetivo em face da administração obtém uma decisão proferida por uma autoridade competente, decisão esta que provavelmente será repetida diante de casos análogos, funcionando como verdadeiro paradigma para futuras situações fáticas de conteúdo semelhante.

Contudo, cada ato que compõe o processo precisa estar de acordo com os princípios processuais, bem como com as leis que regem o processo administrativo.

Alguns desses princípios estão dispostos na própria Constituição Federal, a exemplo dos princípios do contraditório e da ampla defesa, bem como do princípio da vedação da utilização de provas ilícitas no processo, prescritos respectivamente nos incisos LV e LVI da Carta Magna. ${ }^{3}$

Outros ainda estão alocados expressamente na própria de Lei Federal de Processo Administrativo, qual seja, a Lei $n^{\circ}$ 9.784/1999, que, além dos princípios da ampla defesa e do contraditório, também faz constar no seu art. $2^{\circ}$ os seguintes: legalidade, finalidade, motivação, razoabilidade, proporcionalidade, moralidade, segurança jurídica, interesse público e eficiência. ${ }^{4}$

Dessa forma, antes de caracterizar a preclusão administrativa, é relevante destacar preliminarmente dos princípios acima aqueles que mais estão intrinsecamente ligados a ela, quais sejam: o princípio do interesse público, também conhecido no Direito Administrativo como a supremacia do interesse público e o da segurança jurídica.

O princípio da supremacia do interesse público é aquele baseado nas prerrogativas que a Administração possui em face dos particulares, sendo que,

2 CARVALHO FILHO, José dos Santos. E-book. Processo administrativo federal: comentários à lei no 9.784/1999, de 29.1.1999. 5. ed. rev., ampl. e atual. até 31.3.2013. São Paulo: Atlas, 2013, p. 2.

3 BRASIL. CONSTITUIÇÃO FEDERAL, de 5 de outubro de 1988. Constituição da República Federativa do Brasil. Disponível em: <http://www.planalto.gov.br/ccivil 03/constituicao/constituicaocompilado.htm>. Acesso em: $17 \mathrm{dez} .2017$.

4 BRASIL. LEI No 9.784, de 20 de janeiro de 1999. Regula o processo administrativo no âmbito da Administração Pública Federal. Disponível em: <http://http://www.planalto.gov.br/ccivil 03/leis/L9784.htm>. Acesso em: 17 dez. 2017. 
conforme leciona o professor Celso Antônio Bandeira de Mello, pode ser também designado de poderes-deveres. ${ }^{5}$

Adotar uma decisão em um processo administrativo, que procure observar o princípio do interesse público, dentro de uma situação fática, não é tarefa das mais fáceis dentro de um Estado Democrático de Direito, considerando que não há como dissociar o princípio do interesse público à noção de Justiça.

Isso porque o Direito, segundo os dizeres do ilustre professor Miguel Reale, busca realizar a Justiça, e tem como condição original a cultura, sendo que é possível concluir que a justiça sugere o arranjo coerente de relações intersubjetivas, buscando que cada ser humano realize seus valores livremente, mas em sintonia com os da coletividade. ${ }^{6}$

Assim, caberá ao gestor público cumprir a tortuosa missão de decidir buscando o melhor resultado para toda a coletividade, quando a norma permitir mais de uma interpretação, ou até mesmo quando lhe restar responder uma demanda por meio de analogia, visando colmatar a norma, claro que sempre observando as regras de hermenêutica jurídica.

Outro aspecto importante que correlaciona esse mesmo gestor ao princípio da supremacia do interesse público é a relação existente entre a Administração e o processo administrativo. Diferentemente do que acontece no Poder Judiciário, onde as partes não se confundem com o Estado-Juiz, no processo administrativo a Administração, além de ser parte, também faz as vezes de julgador.

Essa importante afinidade pode confundir o gestor, quando faz as vezes de um juiz dentro do processo administrativo, levando-o a decidir conforme ele imagina ser mais conveniente para a Administração, deixando por vezes de observar a melhor técnica jurídica para solucionar o problema, ou, também, decidindo em prejuízo de toda a coletividade.

Aqui entra o importante papel do administrado como cidadão junto ao processo administrativo, mirando buscar o escorreito desfecho dos atos nele praticados, haja vista que no Estado Democrático de Direito o cidadão deve participar

5 BANDEIRA DE MELLO, Celso Antônio. Curso de direito administrativo. São Paulo: Malheiros, 2007, pp. 88-89.

6 REALE, Miguel. Filosofia do direito. 20. ed. São Paulo: Saraiva, 2002, p. 678. 
da "definição e fiscalização (com a decorrente responsabilização estatal eventual) do concreto agir administrativo...." ${ }^{7}$

Portanto, o administrado deverá buscar todos os meios para que tenha o seu direito legalmente respaldado perante à Administração, seja peticionando em face desta, seja interpondo recursos contra decisões arbitrárias ou sem fundamento legal, posto que, mesmo ela sendo parte e juiz ao mesmo tempo no processo Administrativo, isso não lhe dá a chancela para transgredir a norma jurídica, os princípios do Direito e a jurisprudência vinculante, considerando que a sua missão é entregar a melhor decisão para o Estado e, consequentemente, para toda a sociedade.

Nesse momento, é relevante destacar, quanto ao princípio da supremacia do interesse público, a divisão doutrinária que o divide em interesses públicos primários e interesses públicos secundários.

Quanto aos interesses públicos primários, esses surgem quando a Administração exerce a sua estreme função administrativa, em nome do todo, ou seja, do bem maior coletivo e de um bem-estar abrangente; já os interesses públicos secundários são aqueles que advogam em favor da máquina pública administrativa, que independe dos interesses coletivos, normalmente relacionados ao aumento de verbas para a fazenda pública. ${ }^{8}$

Observando a divisão acima, nota-se que o gestor público, ao proferir uma decisão no processo administrativo, em regra não poderá utilizar-se do conceito de interesse público secundário ao entregar uma resposta ao administrado, posto que este refere-se ao bem-estar e ao aparelhamento da própria Administração e não ao alívio do cidadão, que faz parte da coletividade.

Porém, como já mencionado anteriormente, nem sempre é simples decidir no processo administrativo com apoio somente no princípio da supremacia do interesse público, mesmo que no seu viés de interesse público primário, posto que existem outros de igual relevância, a exemplo do princípio da segurança jurídica, também intrinsicamente relacionado à preclusão processual.

FERRAZ, Sérgio, DALLARI, Adilson Abreu. Processo administrativo. 3. ed. São Paulo: Malheiros Editores, 2012, p. 56.

8 NOHARA, Irene Patrícia, MARRARA, Thiago. E-book. Processo administrativo: lei $n^{\circ}$ 9.784/99 comentada. São Paulo: Atlas, 2009, p. 67. 
Como se sabe, conforme previsão contida no texto da Constituição Federal, em seu art. 37, "caput", a Administração Pública tem como um de seus norteadores o princípio expresso da legalidade, o qual, em apertada síntese, significa dizer que ela deve sempre observar o que está prescrito na lei, ou no sistema jurídico, quando da produção de todos os seus atos e procedimentos.

Todavia, existem situações em que, mesmo tendo decidido sem amparo legal ou até mesmo em afronta direta à lei, anular um ato ou todos os atos de um processo administrativo torna-se por demais gravoso ao administrado e à sociedade.

Anular um ato que juridicamente já se consolidou e, consequentemente, produziu efeitos favoráveis ao administrado, fere a noção geral de justiça, bem como a tendência contemporânea de ponderar o poder normativo dos princípios do Direito, em face do descrédito atual do positivismo jurídico e da intempestividade do legislador. ${ }^{9}$

Nesse sentido, o professor José dos Santos Carvalho Filho bem leciona sobre a segurança jurídica, alertando que, em certas circunstâncias, deixar o ato à mercê da instabilidade poderá provocar nas pessoas receios e incertezas, conforme indica a transcrição de sua obra a seguir, litteris:

As teorias jurídicas modernas sempre procuraram realçar a crise conflituosa entre os princípios da legalidade e da estabilidade das relações jurídicas. Se, de um lado, não se pode relegar o postulado de observância dos atos e condutas aos parâmetros estabelecidos na lei, de outro é preciso evitar que situações jurídicas permaneçam por todo o tempo em nível de instabilidade, o que, evidentemente, provoca incertezas e receios entre os indivíduos. A prescrição e a decadência são fatos jurídicos por meio dos quais a ordem jurídica confere destaque ao princípio da estabilidade das relações jurídicas, ou, como se tem denominado atualmente, ao princípio da segurança jurídica. ${ }^{10}$

Isso significa que, transcorrido certo lapso temporal, vindo então a ocorrer a decadência do direito, a prescrição do ato ou a preclusão para o exercício deste no processo, esse mesmo direito não mais poderá ser exigido, requerido ou praticado, em homenagem à confiança na estabilidade das relações jurídicas.

9 SUNDFELD, Carlos Ari et al. Processo administrativo: temas polêmicos da lei $n^{\circ}$ 9.784/99. São Paulo: Atlas, 2011, p. 121.

10 CARVALHO FILHO, José dos Santos. E-book. Manual de direito administrativo. 31. ed. São Paulo: Atlas, 2017, p. 37. 
O mencionado efeito do princípio da segurança jurídica possui correlação com a proteção ao direito adquirido, que está expressamente mencionado no art. $5^{\circ}$, inc. XXXVI da Constituição Federal, destacando-se então como um dos elementos deste princípio.

A Constituição Federal nos alerta que a lei não pode tolher o direito adquirido. ${ }^{11}$ Mas o que seria então o direito adquirido?

Observe-se que a própria de Lei de Introdução às normas do Direito Brasileiro traz um conceito para o aludido direito adquirido, conforme disposto em seu art. $6^{\circ}, \S 2^{\circ}$, a seguir transcrito:

Consideram-se adquiridos assim os direitos que o seu titular, ou alguém por ele, possa exercer, como aqueles cujo começo do exercício tenha termo pré-fixo, ou condição pré-estabelecida inalterável, a arbítrio de outrem. ${ }^{12}$

Depreende-se do texto legal que o direito adquirido é principalmente aquele cujo início foi previamente estabelecido, seja por termo, que depende de um evento futuro e certo, ou mesmo por uma condição, vinculada a um evento futuro e incerto, inalterável ao arbítrio de alguém.

Ao lado do instituto do direito adquirido, caminham juntos ainda o ato jurídico perfeito, que é aquele originado de manifestação de vontade livre e plenamente legal, de "acordo com lei vigente ao tempo em que se efetuou"13, bem como a coisa julgada, que corresponde àquela que não mais permite a interposição de recurso.

Tanto o ato jurídico perfeito como a coisa julgada estão contidas no conceito de direito adquirido, posto que o direito adquirido é mais amplo e, dentro deste, normalmente se encontram um ou mais atos juridicamente perfeitos, que produziram a coisa julgada, da qual não mais é cabível recurso. ${ }^{14}$ Como ensina o

11 BRASIL. CONSTITUIÇÃO FEDERAL, de 5 de outubro de 1988. Constituição da República Federativa do Brasil de 1988. Disponível em: <http://www.planalto.gov.br/ccivil 03/constituicao/constituicaocompilado.htm>. Acesso em: $22 \mathrm{dez} .2017$.

12 BRASIL. DECRETO-LEI N ${ }^{\circ}$ 4.657, de 4 de setembro de 1942. Lei de Introdução às normas do direito brasileiro. Disponível em: <http://www.planalto.gov.br/ccivil 03/decreto-lei/Del4657compilado.htm>. Acesso em: 22 dez. 2017.

13 Idem.

14 TARTUCE, Flávio. Manual de direito civil. 6. ed. rev., atual. e ampl. São Paulo: Método, 2016, p. 27. 
professor Alexandre Freitas Câmara, transcorrido o prazo para a interposição de recurso legalmente previsto, esse não mais poderá ser interposto. ${ }^{15}$

O discorrido até o presente momento ressaltou duas características importantes inerentes ao princípio da segurança jurídica, sendo que a primeira se refere ao seu caráter subjetivo, que versa sobre a conservação dentro do universo jurídico de atos administrativos inválidos; e, a segunda, alusiva ao aspecto objetivo, relacionado ao direito adquirido, ao ato jurídico perfeito e à coisa julgada, que conduzem à irretroatividade de leis e de outras decisões ou atos estatais. ${ }^{16}$

Quanto ao caráter objetivo do princípio da segurança jurídica, cabe destacar que esse desde muito tempo já estava positivado na legislação brasileira, conforme pode ser observado na Lei de Introdução ao Código Civil Brasileiro, assim denominada no ano de 1942, sendo hoje cognominada de Lei de Introdução às Normas do Direito Brasileiro.

À época, a Lei de Introdução ao Código Civil Brasileiro já protegia em seu art. $6^{\circ}$ as "situações jurídicas definitivamente constituídas e a execução do ato jurídico perfeito". 17

É de se notar que o caráter subjetivo do princípio da segurança jurídica, também denominado de princípio da proteção à confiança, até pouco tempo não era tratado pelo Direito Administrativo brasileiro.

Todavia, esse cenário começou a se transformar, posto que ao final da década de 90 surgiram dispositivos legais que trabalham explicitamente com esse conceito, a exemplo dos artigos $2^{\circ}$, par. único, XIII, e 54 da Lei $n^{\circ} 9.784 / 1999^{18}$, sendo que, anteriormente à publicação desta Lei Federal, a Lei do Estado de São Paulo de $\mathrm{n}^{\circ} 10.177 / 1998$ já dispunha em seu art. 10, inc. I, a impossibilidade de a Administração anular determinado ato passados mais de 10 (dez) anos. ${ }^{19}$

15 CÂMARA, Alexandre Freitas. O novo processo civil brasileiro. 2. ed. São Paulo: Atlas, 2016, p. 521.

16 SUNDFELD, Carlos Ari et al. Processo administrativo: temas polêmicos da lei $n^{\circ} 9.784 / 99$. São Paulo: Atlas, 2011, p. 122.

17 BRASIL. DECRETO-LEI N ${ }^{\circ} 4.657$, de 4 de setembro de 1942. Lei de Introdução às normas do direito brasileiro. Disponível em: <http://www.planalto.gov.br/ccivil 03/decreto-lei/Del4657.htm>. Acesso em: 26 dez. 2017.

18 Idem, p. 123.

19 SÃO PAULO. LEI No 10.177, de 30 de dezembro de 1998. Regula o processo administrativo no âmbito da Administração Pública Estadual. Disponível em: <https://www.al.sp.gov.br/norma/?id=7505>. Acesso em: 26 dez. 2017. 
Tomando então a preclusão como instituto processual, mais especificamente aqui voltada para o processo administrativo, verifica-se que esta também é garantidora de segurança para as partes.

Isso porque não é possível dissociar o princípio da segurança jurídica e a preclusão no processo administrativo, haja vista que esta, conforme será desenvolvido nos próximos itens, promove a fiança de não mais ser plausível a prática de determinado ato dentro do processo, em face de cumprimento a um comando legal específico.

\subsection{A preclusão e a sua previsão nas leis brasileiras de processo administrativo}

\subsubsection{Características da preclusão administrativa}

Cada vez mais a sociedade contemporânea exige da Administração Pública providências tempestivas e efetivas, visando soluções para as necessidades ou litígios diversos, como compra de medicamentos, construção de estradas, manutenção de prédios públicos, pagamento de remunerações de servidores, etc.

A maior parte dessas demandas é iniciada por meio de atos administrativos, que são concatenados dentro de um processo, em que todas as partes interessadas são ouvidas, produzem provas e, se necessário, oferecem defesa e contraditório, ao entenderem que a decisão constante de um ato no processo administrativo foi prejudicial aos seus interesses supostamente legítimos.

Esses atos processuais possuem um lapso temporal previsto em lei para serem produzidos, sendo que, caso ultrapassado, em regra não mais poderão ser dirigidos ou repetidos perante à Administração ou à parte interessada.

Nesse mesmo sentido, os ilustres professores Sérgio Ferraz e Adilson Abreu Dallari lecionam sobre a preclusão administrativa, explanando que esta ocorre em face da inércia ou intempestividade de alguma das partes, que deixa de exercer em determinado momento uma faculdade processual. ${ }^{20}$

A perda da possibilidade de praticar um ato processual ocorre frequentemente quando uma das partes se mantém estacionada, após o transcurso

20 FERRAZ, Sérgio, DALLARI, Adilson Abreu. Processo administrativo. 3. ed. São Paulo: Malheiros Editores, 2012, p. 69. 
de certo tempo legal da publicação de uma decisão proferida no processo por uma autoridade competente.

Isso pode ser bem observado no Código de Processo Civil, que estabelece diversos prazos para a prática de atos no decorrer do processo judicial, a exemplo dos mais distintos recursos como Apelação, Agravo de Instrumento, Embargos de Declaração entre outros. Após exceder o limite temporal estabelecido para a interposição de um recurso, surge então a preclusão para esse ato processual, não podendo mais ser praticado.

Cabe destacar que o Código de Processo Civil pode e deve ser utilizado como norte legal para as decisões tomadas dentro do processo administrativo, principalmente quando não existem normas que regem determinada situação fática processual ocorrida perante à Administração.

A ratificar esse entendimento, segue a transcrição do art. 15 do Código de Processo Civil, que dispõe expressamente sobre a possibilidade das normas deste serem aplicadas supletiva e subsidiariamente ao processo administrativo, in verbis: "Art. 15. Na ausência de normas que regulem processos eleitorais, trabalhistas ou administrativos, as disposições deste Código Ihes serão aplicadas supletiva e subsidiariamente."21

Observe-se ainda que existem no processo civil dois tipos de prazos importantes correlacionados à preclusão, quais sejam, os prazos dilatórios e os prazos peremptórios.

Os prazos dilatórios são aqueles que, por meio de uma previsão legal dispositiva, um determinado ato não pode ser praticado, admitindo a sua prorrogação ou até mesmo estipular a sua redução por meio de acordo das partes. Já o prazo peremptório é aquele que não permite qualquer modificação, devendo ser observado fielmente, sob pena de não mais ser possível repetir o ato. ${ }^{22}$

Dos conceitos acima expostos, pode-se concluir então que a preclusão processual é pertinente aos prazos peremptórios, haja vista que a perda da possibilidade de se praticar um ato processual somente ocorre em face de norma

21 BRASIL. LEI No 13.105, de 16 de março de 2015. Código de processo civil. Disponível em: <http://www.planalto.gov.br/ccivil 03/ ato2015-2018/2015/lei/l13105.htm>. Acesso em: $27 \mathrm{dez}$. 2017.

22 ALVIM, José Eduardo Carreira. E-book. Teoria geral do processo. 19. ed. rev., atual. e ampl. Rio de Janeiro: Forense, 2016, p. 261. 
dispositiva, que estabelece um tempo capital para exercê-lo, não podendo existir qualquer convenção das partes em sentido contrário.

Objetivamente, funciona então a preclusão como um verdadeiro impedimento, com a função de proteger o normal caminhar dos atos processuais, evitando que as fases já ultrapassadas venham a sofrer um acuo, e, de forma subjetiva, firma à parte a perda de uma faculdade ou de um direito, seja por ausência do exercício dentro de um tempo legal, ou por já ter sido praticado anteriormente dentro do prazo.

Dessa forma, caso a Administração ou o administrado deixem de promover no momento devido um determinado ato dentro do processo administrativo, ou já o tiver exercido no prazo específico, não mais assistirá a eles o direito de movimentar a máquina administrativa para aquela finalidade, seja por meio de um pedido inicial ou por meio de um recurso.

Considerando o momento do nosso direito contemporâneo, não é possível imaginar o fato de se abdicar da preclusão no processo administrativo, posto que, em qualquer de suas feições (preclusão lógica, temporal ou consumativa), ela é um verdadeiro instrumento garantidor do princípio da segurança jurídica.

Ademais, essa garantia que possuem as partes, no sentido de que, ocorrendo a preclusão, o ato processual não mais poderá ser anulado, repetido ou alterado, é mais relevante do que a divisão da preclusão em temporal, lógica ou consumativa, mesmo porque essa classificação não é pacificamente aceita por todos os doutrinadores. Nesses termos, segue a transcrição de lição do professor Rosemiro Pereira Leal, a corroborar esse juízo, in verbis:

A preclusão é a maior garantia das partes de que a estrutura do procedimento não pode ser alterada ou anulada por atos de arbítrio, conveniência, revisão, retorno, reabertura, cancelamento, recomeço, senão pelos modos que a lei rigorosamente impuser. Entendemos que não é satisfatória a classificação da preclusão em temporal, lógica e consumativa, porque a preclusão é sempre lógico-jurídico-temporal. ${ }^{23}$

Todavia, cabe ressaltar que em algumas situações fáticas, em nome dos princípios orientadores do processo administrativo, como a verdade material e do formalismo moderado, a doutrina orienta que a preclusão seja relevada.

23 LEAL, Rosemiro Pereira. (05/2014). Teoria geral do processo: primeiros estudos. 12. ed. rev. e atual. Rio de Janeiro: Forense, 2014. [Minha Biblioteca]. Retirado: <https://integrada.minhabiblioteca.com.br/\#/books/978-85-309-5637-0/>. 
Isso porque os doutrinadores vêm constantemente reconhecendo que a preclusão não deve ser tomada como instituto que bloqueie correções administrativas, em face de situações que envolvam o interesse público. ${ }^{24}$

Resta agora analisar como a garantia processual da preclusão está positivada nas normas processuais brasileiras, conforme subitem a seguir.

\subsubsection{As leis brasileiras e a preclusão administrativa}

A bem da verdade, os diplomas legislativos brasileiros não tratam com tanta especificidade sobre o instituto da preclusão no processo administrativo brasileiro.

Além do mais, como bem explicitado pelos professores Sérgio Ferraz e Adilson Abreu Dallari, nem mesmo o Código de Processo Civil de 1973 trazia em seu bojo um estudo mais sistematizado sobre o assunto, optando por "cuidar de pontos em que incidiriam o conceito e os efeitos da preclusão (v.g., arts. 183 e 245, ambos no caput)". ${ }^{25}$

Ao compulsar o novo Código de Processo Civil, correlacionando com os dispositivos acima mencionados que tratavam da preclusão no Código de Processo Civil de 1973, observa-se que o legislador também optou por não sistematizar o instituto processual da preclusão, posto que a novel lei de codificação do processo civil apenas realizou, por meio de seu art. 223, alguns ajustes na redação do antigo art. 183 do CPC de 1973, e, ainda, repetiu em seu art. 278 o conteúdo do art. 245 do CPC de $1973 .{ }^{26}$

Quanto ao Direito Administrativo, observa-se que a Lei nº 8.112/1990, embora não tenha tratado dela explicitamente, estabeleceu em seu Capítulo VIII, nos artigos 104 ao 115, as regras para se peticionar junto à Administração, fixando prazo para o requerimento de pedidos, para a interposição de recursos e para a configuração da prescrição.

24 CARVALHO FILHO, José dos Santos. E-book. Processo administrativo federal: comentários à lei n 9.784/1999, de 29.1.1999. 5. ed. rev., ampl. e atual. até 31.3.2013. São Paulo: Atlas, 2013, p. 83.

25 FERRAZ, Sérgio, DALLARI, Adilson Abreu. Processo administrativo. 3. ed. São Paulo: Malheiros Editores, 2012, p. 70.

26 BRASIL. LEI No 13.105, de 16 de março de 2015. Código de processo civil. Disponível em: <http://www.planalto.gov.br/ccivil 03/ ato2015-2018/2015/lei//13105.htm>. Acesso em: 29 dez. 2017. 
Em seu art. 115, a Lei n 8.112/1990 dispôs que "são fatais e improrrogáveis os prazos estabelecidos neste Capítulo, salvo motivo de força maior"27, deixando claro que os prazos do Capítulo VIII desta norma são peremptórios, e, consequentemente, caso extrapolados, impediriam o andamento processual, estabelecendo assim uma verdadeira regra de preclusão.

Posteriormente, a Lei $n^{\circ} 10.177 / 1998$ do Estado de São Paulo foi publicada com o intuito de organizar o processo administrativo paulista, mas nem mesmo fez qualquer referência sobre o instituto da preclusão.

Em seguida, publicou-se a tão difundida Lei Federal nº 9.784/1999, que também não tratou de forma zelosa sobre a preclusão, mas ao menos fez uma menção a ela no seu art. $63, \S 2^{\circ}$, prescrevendo que o não reconhecimento do recurso administrativo não seria capaz de impedir a revisão de ofício do ato ilegal pela Administração, desde que não ocorrida a preclusão administrativa. ${ }^{28}$

Embora não haja na Lei n 9.784/1999 um tratamento sistematizado sobre os efeitos da preclusão administrativa, constata-se que essa norma atribuiu admirável valor a ela, posto que, caso o ato pretendido por uma das partes esteja precluso, nem mesmo a revisão de ofício por parte da Administração será possível.

A jurisprudência do Superior Tribunal de Justiça caminha também nesse mesmo sentido, conforme pode ser observado da transcrição de parte da Ementa do Agravo Regimental no Mandado de Segurança $\mathrm{n}^{\circ} 7.897 / \mathrm{DF}^{29}$, ipsis litteris:

AGRAVO REGIMENTAL. RECURSO ADMINISTRATIVO. LEI N. ${ }^{\circ}$ 9.784/1999. INTERPOSIÇÃO. OFERECIMENTO DAS RAZÕES APÓS O TÉRMINO DO PRAZO RECURSAL. MOTIVO DE FORÇA MAIOR NÃO COMPROVADO. CONJUNTO PROBATÓRIO INEXISTENTE. PRINCÍPIO DA PRECLUSÃO CONSUMATIVA E DA SEGURANÇA JURÍDICA. AGRAVO DESPROVIDO. I - O recurso administrativo deve ser interposto com as razões do pedido de reforma. II - O prazo para o recurso é peremptório e contínuo, ou seja, ultrapassado o lapso temporal ou exercido o direito de recorrer se opera a preclusão consumativa para a prática de qualquer ato relacionado com a interposição do recurso, em homenagem ao princípio da preclusão consumativa e da segurança jurídica [...].

27 BRASIL. LEI № 8.112, de 11 de dezembro de 1990. Dispõe sobre o regime jurídico dos servidores públicos civis da União, das autarquias e das fundações públicas federais. Disponível em: <http://www.planalto.gov.br/ccivil 03/leis/L8112cons.htm>. Acesso em: 30 dez. 2017

28 FERRAZ, Sérgio, DALLARI, Adilson Abreu. Processo administrativo. 3. ed. São Paulo: Malheiros Editores, 2012, p. 69.

29 SUPERIOR TRIBUNAL DE JUSTIÇA. Agravo Regimental no Mandado de Segurança $\mathbf{n}^{\circ} 7.897$ DF. Relatora: Laurita Vaz. Pesquisa de Jurisprudência, Acórdãos, Brasília, 04 mar. 2002. Disponível em: $\quad<$ http://www.stj.jus.br/SCON/jurisprudencia/toc.jsp?livre=\%28\%22LAURITA+VAZ\%22\%29.min.\&processo=7897\&\&b=ACOR\&thesaurus=JURIDICO\&p=true $>$. Acesso em: 02 jan. 2018. 
É de se ressaltar ainda que nos demais Estados da Federação há uma tendência de apenas reproduzir a pequena referência contida na Lei Federal 9.784/1999 sobre a preclusão administrativa, aproveitando para citar como exemplos as leis estaduais de processo administrativo do Estado de Goiás ${ }^{30}$ e do Estado do Rio de Janeiro. ${ }^{31}$

Dessa maneira, em face de insuficiência normativa, no que diz respeito à ausência de sistematização dos efeitos da preclusão no processo administrativo, a decisão sobre casos concretos de difícil solução deverá adotar como solução o que já foi firmado pela jurisprudência, a exemplo do que se denominou de "prescrição do fundo de direito", conforme será visto posteriormente, no capítulo que trata sobre prescrição.

30 GOIÁS. LEI No 13.800 , de 18 de janeiro de 2001. Regula o processo administrativo no âmbito da Administração Pública do Estado de Goiás. Disponível em: <http://www.gabinetecivil.goias.gov.br/leis ordinarias/2001/lei 13800.htm>. Acesso em: 30 dez. 2017.

31 RIO DE JANEIRO. LEI N ${ }^{\circ} 5427$, de 01 de abril de 2009. Estabelece normas sobre atos e processo administrativo no âmbito do Estado do Rio de Janeiro e dá outras providências. Disponível em: <http://www.aleri.ri.gov.br/>. Acesso em: 30 dez. 2017. 


\section{CAPÍTULO 2: PRESCRIÇÃO E DECADÊNCIA}

Esse capítulo versará especificamente sobre a prescrição e decadência, fornecendo elementos jurídicos para distinguir e identificar esses dois institutos relevantes do direito material, que, em alguns casos, podem tornar a decisão administrativa inalcançável.

A prescrição e a decadência são matérias que podem decidir o processo sem a necessidade de enfrentamento do mérito propriamente dito, e, devido ao impacto que eles exercem sobre específica situação fática administrativa, merecem a análise cuidadosa de seus alcances.

Ambas colocam um limite temporal para se alcançar ou modificar determinado ato ou decisão, e, por isso, surge a necessidade de se destacar, dentre outros, o princípio da segurança jurídica, haja vista que a modificação de uma decisão, ultrapassando a barreira legal fixada na escala de tempo, pode perturbar a paz social.

Contudo, como se verá no desenvolver desse capítulo, há momentos em que o princípio da segurança jurídica poderá colidir com o princípio do interesse público, e, nessas ocasiões, importante ressaltar quais instrumentos legais e jurisprudenciais dispõe o gestor para decidir em consonância com o ordenamento jurídico vigente no nosso país.

Por último, será feita ainda uma abordagem dos principais instrumentos legais e jurisprudenciais que envolvem os institutos da prescrição e decadência, os quais estão à disposição do gestor, devendo este observá-los para dar a melhor solução jurídica à determinado caso concreto.

\subsection{Efeitos da prescrição e decadência no processo administrativo}

2.1.1 Aspectos básicos da prescrição e decadência no código civil, e os seus reflexos no campo processual

Uma das dimensões mais importantes para a Ciência Jurídica é o tempo. Por meio do transcurso do tempo pode-se adquirir, modificar e extinguir direitos. 
A relevância do tempo para as relações no Direito pode ser exemplificada por meio da evolução de nossa capacidade para praticar os atos da vida civil.

Conforme dispõe o art. $3^{\circ}$ do Código Civil, a pessoa inicia sua vida absolutamente incapaz para praticar os atos da vida civil, até se tornar relativamente capaz para exercê-los após completar os 16 anos, e, posteriormente, plenamente capaz aos 18 anos, conforme prescrevem respectivamente os artigos $4^{\circ}$, inc. I e $5^{\circ}$, ambos do Código Civil. ${ }^{32}$

Constata-se ainda que o tempo está umbilicalmente conexo a uma das maiores razões de ser da Ciência Jurídica, qual seja, a pacificação social. É por meio do Direito que os cidadãos de determinado Estado, ao se submeterem à lei, alcançam a estabilização das relações jurídicas praticadas por eles, o que confere segurança para a prática de diversos atos, sejam negociais ou não.

O momento em que determinado suporte fático foi formado, alterado ou extinto, é de grande relevância para aquele que detém a capacidade de decidir um litígio, posto que embora alguma das partes ainda tenha o interesse no bem da vida pretendido, a norma pode prescrever que, pelo transcurso temporal, ele não mais será alcançado.

Ademais, para que seja preservado o sentimento de estabilidade social, bem como a garantia de segurança jurídica, não se pode permitir a fixação de relações legais que se perpetuem ad eternum, obrigando a outra parte a se submeter ao infindável juízo do titular de um direito, sem qualquer limitação de tempo. ${ }^{33}$

Visando então assegurar a já mencionada estabilidade das relações jurídicas, a norma previu os institutos da prescrição e decadência, sendo que neste momento ocupa-se de melhor caracterizá-los.

Quando ainda vigente o Código Civil de 1916, existia muita desordem para tentar distinguir a aplicação da prescrição ou da decadência em face das situações fáticas que ocorriam.

O Código Civil de 1916 trazia todos os prazos prescricionais ou decadenciais em sua Parte Geral, denominando-os apenas de prescrição, fazendo

32 BRASIL. LEI № 10.406, de 10 de janeiro de 2002. Código civil. Disponível em: <http://www.planalto.gov.br/ccivil 03/leis/2002/L10406.htm>. Acesso em: 03 jan. 2018.

33 GAGLIANO, Pablo Stolze, PAMPLONA FILHO, Rodolfo. E-book. Novo curso de direito civil v. 1: parte geral. 19. ed. São Paulo: Saraiva, 2017, p. 534. 
com que a doutrina se encarregasse da missão hercúlea de distingui-los diante do caso concreto que lhe era apresentado.

Nesse sentido, importante trazer à baila afirmação constante do livro do professor Paulo Nader ${ }^{34}$, conforme transcrição a seguir, in verbis:

Como o Código Beviláqua não distinguiu uma figura da outra - em seu texto sequer aparece o vocábulo decadência -, tratando toda a matéria sob a epígrafe Da Prescrição, as distinções ficaram por conta da doutrina e da jurisprudência, avolumando-se os estudos a respeito e dos quais resultou o amplo paralelo a seguir focalizado.

Devido a essa problemática, como bem explica Flávio Tartuce, o ilustre professor Agnelo Amorim associou o instituto da prescrição às ações de cunho condenatório, ou seja, àquelas derivadas de uma prestação, originada de pretensões particulares, correlacionadas às obrigações e deveres, cujo encargo origina-se da não observância de normas e regras fixadas pelas partes ou pela lei. ${ }^{35}$

De outra banda, a decadência refere-se a um prazo para o exercício de um direito potestativo, que nasce de uma determinada relação jurídica, direito este cujo titular, pode, unilateralmente, desconstitui-lo ou modificá-lo. Daí, observa-se que ele está claramente vinculado às ações que constituem um direito, denominadas de "constitutivas".

O Código Civil de 2002, com o intuito de solucionar os problemas na aplicação da prescrição e decadência, adotou então a teoria de Agnelo Amorim, resolvendo definir os prazos prescricionais nos seus artigos 205 e 206, sendo que qualquer outro prazo constante deste código seria um prazo decadencial, findando assim o vozerio então pendente na doutrina.

Nesse momento, cabe salientar que os ilustres professores Cristiano Chaves, Felipe Braga Netto e Nelson Rosenvald destacam que, atualmente, não é mais prestigiada a simples distinção anterior que se fazia entre prescrição e decadência, que consiste na afirmação de que a primeira extingue a ação e a segunda finda o direito. ${ }^{36}$

34 NADER, Paulo. E-book. Curso de direito civil - vol. 1: parte geral. 10. ed. rev. e atual. Rio de Janeiro: Forense, 2016, p. 566.

35 TARTUCE, Flávio. Manual de direito civil: volume único. 6. ed. São Paulo: Método, 2016, p. 310.

36 FARIAS, Cristiano Chaves de, NETTO, Felipe Braga, ROSENVALD, Nelson. Manual de direito civil: volume único. Salvador: JusPodivm, 2017, p. 591. 
Contemporaneamente, leciona-se que a prescrição está relacionada ao direito a uma prestação, que pode ser transgredida por alguma das partes, denominada de sujeito passivo. Somente esses direitos se submetem à prescrição.

Assim, violado o direito surge uma pretensão, que é vinculada a uma prestação, e sua exigibilidade poderá sofrer a prescrição, passado determinado prazo legal estabelecido.

Quanto à decadência, como já mencionado acima, essa se vincula então aos direitos que podem ser praticados unilateralmente por seu detentor, independentemente da atuação da outra parte ou de terceiros. Tais direitos são denominados de potestativos e não podem ser violados, sendo que não se submetem à prescrição e sim à decadência.

Sobre a prescrição, o art. 189 do Código Civil dispõe o seguinte: "violado o direito, nasce para o titular a pretensão, a qual se extingue, pela prescrição, nos prazos a que aludem os arts. 205 e 206 ". 37

Da leitura do dispositivo acima, verifica-se que o Código Civil ensinou que a prescrição extingue a pretensão.

Mas o que diz a doutrina? Estaria certo afirmar que a pretensão é extinta pela prescrição?

Nesse momento, cabe mencionar a argumentação do eminente professor Marcos Bernardes de Mello, no sentido de que a prescrição e decadência estão conexas às situações em que as partes permanecem inativas, não exercendo determinados direitos durante um certo lapso de tempo, de maneira intencional ou não, conduzindo ao seu prejuízo ou ao seu encobrimento. Por esse ângulo, a prescrição e decadência são classificadas como ato-fato jurídico caducificante. ${ }^{38}$

Esse mesmo autor afirma ainda que a decadência extingue determinado direito e, por conseguinte, a pretensão. Já a prescrição apenas encobre a pretensão, ou melhor, apenas inibe a exigibilidade ou o caráter impositivo do direito, não impedindo que esse seja adimplido.

37 BRASIL. LEI No 10.406, de 10 de janeiro de 2002. Código civil. Disponível em: <http://www.planalto.gov.br/ccivil 03/leis/2002/L10406.htm>. Acesso em: 03 jan. 2018.

38 MELLO, Marcos Bernardes de. Teoria do fato jurídico: plano da existência. 20. ed. São Paulo: Saraiva, 2014, p. 188. 
Conclui-se do acima exposto não ser escorreito afirmar que a prescrição extingue a pretensão, posto que somente a encobre, sendo que o direito subjetivo, caso não tenha transcorrido o prazo decadencial, permanece intacto.

Embora pareça, em um primeiro momento, apenas mais uma teoria cuja importância está limitada aos debates acadêmicos, isso tem uma relevância prática, que reflete no campo processual, haja vista que, em um processo judicial ou administrativo, dificilmente a parte não irá alegar o transcurso do prazo prescricional caso ele tenha sido alcançado.

No que diz respeito ao decurso do prazo decadencial, transcorrido esse, fulminado está o direito e, consequentemente, a pretensão, não existindo assim razão para ser instaurado o processo ou dar continuidade a ele.

As causas de impedimento, suspensão e interrupção da prescrição dispostas no Código Civil, mais precisamente nos artigos 197 ao 204, também produzem reflexos no processo e, por isso, é fundamental para o presente trabalho mencioná-las.

O impedimento da prescrição proíbe que o prazo comece a correr em face das hipóteses legalmente previstas nos artigos 197 ao 199 do CC. Nesse caso, a prescrição nem mesmo chega a se encetar.

No entanto, caso o prazo prescricional já tenha se iniciado e, posteriormente, venha a surgir qualquer das causas legais estabelecidas nos artigos 197 ao 199 do CC, suspensa estará a prescrição, cujo prazo voltará a correr de onde acuou, ou seja, será aproveitado no cômputo do prazo prescricional o tempo transcorrido antes da suspensão.

Distintamente acontece com a interrupção, disposta nos artigos 202 ao 204 do Código Civil, sendo que nesta, ocorrida a situação fática prevista na norma legal como ensejadora de interrupção da prescrição, o prazo prescricional é totalmente devolvido, sendo que, ao desaparecer a causa que obstruiu a prescrição, o prazo voltará a correr do início.

A importância do impedimento, da interrupção e da suspensão é revelada em face do zelo a ser observado pelas partes para se evitar o transcurso do prazo prescricional, seja antes ou durante o decorrer do processo, buscando os litigantes adotar alguma das providências dispostas em lei, a exemplo de promover 
ato judicial que constitua o devedor em mora, conforme dispõe o art. 202, inc. $V$ do CC. ${ }^{39}$

Ainda, quanto aos reflexos da prescrição sobre o processo, cabe também ressaltar a recente alteração ocorrida no Código Civil, promovida pela Lei $\mathrm{n}^{\circ}$ 13.146/2015, denominada de Estatuto da Pessoa com Deficiência.

Imaginemos que determinado servidor público, já próximo a completar o tempo para a sua aposentação, deseje entrar com um processo administrativo, visando averbar tempo de contribuição prestado ao serviço público de outro ente, período este que irá complementar o prazo restante para preencher os requisitos constitucionais de sua futura aposentadoria.

Contudo, poucos meses antes de entrar com o processo, o servidor é acometido por uma doença mental assaz incapacitante, impossibilitando-o de exercer os atos da vida civil.

Anteriormente à vigência da Lei $\mathrm{n}^{\circ}$ 13.146/2015, o cidadão com deficiência física ou mental poderia ser enquadrado como absolutamente incapaz.

Um benefício constante desse enquadramento é que o prazo prescricional não correria para o administrado absolutamente incapaz. Assim, a partir da mudança no Código Civil promovida pelo Estatuto da Pessoa com Deficiência, o deficiente físico ou mental não mais poderá fazer uso desse benefício, ao menos se considerarmos a rigorosidade da lei.

A forma de solucionar o problema acima deverá ser questão de ampla discussão, tanto na jurisprudência como na doutrina e, conforme ressalta os professores Cristiano Chaves, Felipe Braga Netto e Nelson Rosenvald, "talvez não existam respostas prontas, apriorísticas, talvez as soluções precisam ser equitativas e banhadas pela razoabilidade que deflui dos casos concretos". ${ }^{40}$

Ao correlacionar as características principais da prescrição e decadência no âmbito do Direito Civil, com a realidade do processo administrativo, pode-se chegar a interessantes conclusões.

Como exemplo, pode-se defender que a Administração, em um primeiro momento, não deveria abrir mão do interesse público e dispensar

39 BRASIL. LEI № 10.406, de 10 de janeiro de 2002. Código civil. Disponível em: <http://www.planalto.gov.br/ccivil 03/leis/2002/L10406.htm>. Acesso em: 18 jan. 2018.

40 FARIAS, Cristiano Chaves de, NETTO, Felipe Braga, ROSENVALD, Nelson. Manual de direito civil: volume único. Salvador: JusPodivm, 2017, p. 595. 
determinado administrado da devolução de parcela irregularmente percebida por ele, para os casos em que já tenha transcorrido o prazo prescricional, posto que, nesse caso, se vier a se sentir prejudicado, poderá ou não o administrado fazer uso do escudo do instituto da prescrição.

Ademais, no que diz respeito à prescrição, existe a teoria das prestações de trato sucessivo, cujo prazo prescricional se renova ao recebimento de cada parcela, cujas características ainda serão tratadas no último capítulo desse trabalho.

Após essas considerações sobre prescrição e decadência no âmbito do Direito Civil, com os seus consectários processuais, passa-se agora a expor acerca da prescrição no campo do Direito Administrativo e, consequentemente, seus efeitos processuais, que é o enfoque do presente trabalho.

\subsubsection{Características da prescrição no direito administrativo}

No Direito Administrativo, não distintamente de outros ramos do Direito, a prescrição tem o condão de proteger a estabilidade das relações jurídicas.

Ao passar dos anos, as situações concretas que ensejaram um determinado direito ou um dever vão ficando distantes na memória dos atores e, de fato, vão se consolidando em seus espíritos.

Não é possível imaginar no Direito contemporâneo, seja público ou privado, ausência de normas que estabeleçam um prazo prescricional, posto que isso seria uma ofensa a qualquer ordenamento jurídico que deseja manter a pacificação social.

A imprescritibilidade, em regra, é algo que ofende a moral. Nesse sentido, importante os ensinamentos do professor Elody Nassar, ao dizer que "a imprescritibilidade desponta em todas as disciplinas jurídicas como imoral e atentatória à estabilidade das relações sociais, sendo exceção à regra geral da prescritibilidade dos direitos." ${ }^{41}$.

Todavia, sabe-se que o Direito Administrativo é uma matéria autônoma, e por isso faz-se necessário trazer à baila alguns contornos da prescrição administrativa.

41 NASSAR, Elody. E-book. Prescrição na administração pública. 2. ed. rev. e atual. São Paulo: Saraiva, 2009, p. 9. 
Em um primeiro momento, cabe ressaltar que a prescrição administrativa nada mais é que a perda do limite para o oferecimento de um pedido, de um recurso ou até mesmo a perda, por parte da Administração de se impor ao administrado uma revisão de determinada decisão administrativa que lhe tenha beneficiado.

Segundo ensinamentos dos professores Sérgio Ferraz e Adilson Abreu Dallari, esse limite temporal, no que diz respeito à prescrição, está ligado ao prazo para se intentar a ação jurisdicional, e não ao próprio direito em si, este correlacionado com a decadência ${ }^{42}$.

Dentro do Direito Administrativo, a prescrição deverá observar alguns princípios do Direito Público, que são orientadores dessa ciência, sendo que os mais basilares para essa finalidade são a supremacia do interesse público sobre o privado e a indisponibilidade do interesse público.

O princípio da supremacia do interesse público já foi bastante mencionado no capítulo anterior desse trabalho e, nesse momento, caber tecer seus aspectos relevantes para a prescrição administrativa.

Saliente-se, de início, que no Direito Civil as posses, os bens e os negócios podem, em regra, ser dispostos livremente pelas partes, enquanto que no Direito Administrativo esses devem ser conduzidos pelo gestor com observância da lei e dos princípios gerais do Direito Público, a bem da coletividade, em detrimento das vontades pessoais das partes.

Clara predominância do interesse público sobre o privado, no que diz respeito ao instituto da prescrição, pode ser observada na Lei $n^{\circ}$ 9.784/1999, mais precisamente em seu art. $26, \S 5^{\circ}$, que prescreve a possibilidade de se relevar a nulidade de uma intimação que não tenha observado as prescrições legais, caso o administrado venha a comparecer ${ }^{43}$, tornando assim o processo mais tempestivo e desburocratizado.

Apesar disso, a observância ao princípio da supremacia do interesse público sobre o privado não pode ser utilizada como pretexto para acobertar ilegalidades da Administração, afastando os direitos dos administrados previstos em

42 FERRAZ, Sérgio, DALLARI, Adilson Abreu. Processo administrativo. 3. ed. São Paulo: Malheiros Editores, 2012, p. 267.

43 BRASIL. LEI No 9.784 , de 20 de janeiro de 1999. Regula o processo administrativo no âmbito da Administração Pública Federal. Disponível em: <http://http://www.planalto.gov.br/ccivil 03/leis/L9784.htm>. Acesso em: 25 jan. 2018. 
lei, embora tal princípio seja empregado para restringir alguns direitos, em nome de toda a coletividade.

Saliente-se ainda, no que diz respeito à divisão clássica entre interesse público primário e secundário, já mencionada nesse trabalho, que somente quanto ao primário é que poderá existir a predominância sobre o interesse privado, posto que é no primário que o Estado busca a harmonização da coletividade, buscando promover segurança e bem-estar social.

Quanto ao princípio da indisponibilidade do interesse público, também fundamental para a prescrição administrativa, cabe exaltar as principais características que os correlacionam.

O principal elemento a ser tratado no que diz respeito à prescrição em face da indisponibilidade do interesse público diz respeito à renúncia.

Poderia a Administração, ao se debruçar sobre um pedido de um administrado, renunciar à prescrição, e, assim, abrir mão do interesse público?

Conforme ressalta o reluzente professor Elody Nassar, o Supremo Tribunal Federal tem o entendimento de que somente a lei poderia autorizar a renúncia à prescrição, exatamente por considerar o princípio da indisponibilidade do interesse público, conforme observa-se do seguinte excerto de seu trabalho, ao dizer que "em decorrência desse princípio o Supremo Tribunal Federal já decidiu que o poder de transigir ou de renunciar não se configura se a lei não o prevê". ${ }^{44}$

Renúncia à prescrição é então não invocá-la diante de um fato concreto, podendo ser feita de forma explícita/expressa ou subentendida/tácita.

É expressa quando o gestor, em nome da Administração, afasta a sua incidência para que a demanda do administrado seja examinada quanto ao mérito. De outra banda, é implícita quando, transcorrido o lapso temporal prescricional, o administrador público deixa de considerá-la em sua decisão, examinando o mérito da situação fática e de direito sem mesmo levantar essa questão.

O desejo de resguardar a indisponibilidade do interesse público também reflete no conteúdo legal das normas administrativas que tratam sobre a prescrição. Basta ver o disposto no art. 112 da Lei n 8.112/1990, que, ao afirmar ser

44 NASSAR, Elody. E-book. Prescrição na administração pública. 2. ed. rev. e atual. São Paulo: Saraiva, 2009, p. 107. 
a prescrição de ordem pública, não podendo ser relevada ${ }^{45}$, deixa evidente a preeminência desse princípio em face da vontade dos administrados, que, nesse caso, trata-se do servidor público federal.

Cabe então, nesse momento, fazer o seguinte questionamento: é possível relevar a prescrição administrativa, em face do princípio da indisponibilidade do interesse público?

Nesse sentido, depreende-se da leitura de alguns doutrinadores que não seria possível vencer o prazo prescricional para iniciar ou praticar um ato novo dentro do processo. A exemplo, aproveita-se para citar entendimento do ilustre professor Diógenes Gasparini, in verbis:

Nada justifica a possibilidade de um ato administrativo vir a ser declarado inválido depois de um longo tempo de sua edição. Ao entender-se isso factível, estar-se-ia pondo em risco a necessária estabilidade das relações jurídicas após certo tempo de vigência. Destarte, decorrido determinado prazo, o ato ilegal firma-se, estabilizase, não podendo mais ser invalidado pela Administração Pública ou anulado pelo Judiciário. ${ }^{46}$

No entanto, privilegiar sempre a aplicação do princípio da legalidade em detrimento ao princípio da segurança jurídica pode resultar em situações em que o dano provocado à sociedade é muito maior, desvirtuando assim uma das finalidades do Direito, que é a pacificação social.

Com esse espírito, a Lei $n^{\circ}$ 9.784/1999 previu em seu texto o já mencionado nesse trabalho art. $63, \S 2^{\circ}$, o qual prescreve que o "não conhecimento do recurso não impede a Administração de rever de ofício o ato ilegal, desde que não ocorrida preclusão administrativa". ${ }^{47}$

Note-se que o dispositivo acima mencionado não é muito esclarecedor, mormente sobre como aplicá-lo perante um caso concreto, principalmente se a preclusão administrativa, a qual faz referência, produziria efeitos para o administrado ou para a Administração.

45 BRASIL. LEI No 8.112, de 11 de dezembro de 1990. Dispõe sobre o regime jurídico dos servidores públicos civis da União, das autarquias e das fundações públicas federais. Disponível em: <http://www.planalto.gov.br/ccivil 03/leis/L8112cons.htm>. Acesso em: 26 jan. 2018.

46 GASPARINI, Diógenes. Direito administrativo. 20. ed. rev. e atual. São Paulo: Saraiva, 2003, p. 110.

47 BRASIL. LEI No 9.784, de 20 de janeiro de 1999. Regula o processo administrativo no âmbito da Administração Pública Federal. Disponível em: <http://www.planalto.gov.br/ccivil 03/leis/L9784.htm>. Acesso em: 28 jan. 2018. 
No entanto, utilizando-se de uma interpretação que privilegie o interesse público, e, ainda, com o intuito de não se esvaziar a possibilidade de aplicação da norma, depreender-se-ia que, apresentado um recurso intempestivo pelo administrado dentro de um processo administrativo, e, por tanto, já precluso, a Administração poderia conhecê-lo de ofício, desde que a preclusão não tivesse corrido para esta, ou seja, o termo "preclusão administrativa" pertenceria à perda da faculdade processual de a Administração praticar o ato e não o administrado.

Ademais, cabe salientar que está demasiadamente difundida nos dias atuais a utilização de princípios para a solução de litígios. Os princípios possuem múltiplas funções, e são carregados de uma capacidade argumentativa, e, por isso, mais abarcantes, como bem ensinam o ministro do Supremo Tribunal Federal Gilmar Ferreira Mendes e o ilustre professor Paulo Gustavo Gonet Branco. ${ }^{48}$

Por isso, defende-se nesse trabalho que, caso presente o interesse público, o transcurso do prazo prescricional pode ser superado, a exemplo de situações de perda de prazo por parte do administrado para interposição de recurso, em face de alguma prestação com curta vigência temporal que the deixou de ser conferida, aplicando-se ao caso concreto os princípios da verdade real, do formalismo mitigado e da autotutela administrativa, ambos orientadores da atuação do gestor da administração pública.

Corroborando esse entendimento, principalmente no que diz respeito ao papel do julgador ao ponderar princípios em face do rigor literal da lei, importante transcrever parte da ementa do Recurso Especial 1109357/RJ49, proferido pela ministra do Superior Tribunal de Justiça Nancy Andrighy, ipsis litteris:

\section{(...)}

- A declaração de preclusão do direito à produção de prova pericial não é razoável unicamente porque a parte depositou os honorários periciais com quatro dias de atraso. Trata-se de excessivo rigor formal, que não se coaduna com o princípio da ampla defesa,

sobretudo considerando a inexistência de qualquer prejuízo para a parte contrária, tampouco para o perito judicial.

- Além do compromisso com a Lei, o juiz tem um compromisso com a Justiça e com o alcance da função social do processo para que este não se torne um instrumento de restrita observância da forma se

48 MENDES, Gilmar Ferreira, BRANCO, Paulo Gustavo Gonet. E-book. Curso de direito constitucional. 12. ed. rev. e atual. São Paulo: Saraiva, 2017, p. 72.

49 SUPERIOR TRIBUNAL DE JUSTIÇA. Recurso Especial $\mathbf{n}^{\circ} 1109357$ - RJ. Relatora: Nancy Andrighy. Pesquisa de Jurisprudência, Acórdãos, Brasília, 01 jul. 2010. Disponível em: $<$ http://www.stj.jus.br/SCON/jurisprudencia/toc.jsp?processo=1109357\&\&b=ACOR\&thesaurus=JU RIDICO\&p=true> . Acesso em: 28 jan. 2018. 
distanciando da necessária busca pela verdade real, coibindo-se o excessivo formalismo.

- Conquanto mereça relevo o atendimento às regras relativas à técnica processual, reputa-se consentâneo com os dias atuais erigir a instrumentalidade do processo em detrimento ao apego exagerado ao formalismo, para melhor atender aos comandos da lei e permitir o equilíbrio na análise do direito material em litígio.

Recurso especial provido.

Finalmente cabe ainda avultar, no que tange aos prazos prescricionais, que estes estão dispersos nas múltiplas leis administrativas dos diversos entes do país, e, em alguns casos, a doutrina aponta a existência de imprecisão técnica na norma ao chamar de "prescrição" o que deveria ter sido nomeado de decadência, conforme será tratado no próximo subcapítulo desse trabalho.

\subsubsection{Características da decadência no direito administrativo}

A decadência também assume importante relevo perante o Direito Administrativo, sendo que a sua origem decorre da mesma necessidade de estabilização das relações jurídicas que, no campo do Direito Público, também possui contornos específicos.

Não distintamente da prescrição, a decadência no campo do Direito Administrativo deve ser avaliada sob o crivo dos princípios da supremacia do interesse público sobre o privado e da indisponibilidade do interesse público.

A decadência, como já trabalhado em outra oportunidade, diz respeito ao próprio direito e às ações do tipo constitutivas. Dessa forma, alcançado o transcurso do prazo decadencial, não mais caberia à parte anulá-lo ou invalidá-lo, posto que o próprio direito foi fulminado.

Esse direito de anular ou invalidar um ato, e o respectivo prazo para tanto, é bem trabalhado por vastos doutrinadores.

Os eminentes autores Romeu Felipe Bacellar Filho e Ricardo Marcondes Martins ${ }^{50}$ lecionam que três são as teorias amplamente divulgadas pela doutrina sobre o limite temporal para se invalidar um ato, quais sejam: a) corrente negativa; b) corrente afirmativo-dicotômica; c) corrente afirmativo-unitária.

50 BACELLAR FILHO, Romeu Felipe, MARTINS, Ricardo Marcondes. Ato administrativo e procedimento administrativo. São Paulo: Revista dos Tribunais, 2014, pp. 301-302. 
A corrente negativa ensina que, caso não haja o estabelecimento de um tempo para a invalidação de determinado ato, este poderá ser invalidado a qualquer tempo.

Já para conceituar a corrente afirmativo-dicotômica, faz-se necessário primeiramente distinguir, em apertada síntese, ato nulo de anulável, embora alguns doutrinadores não possuam apreço por esta distinção.

$\mathrm{O}$ ato nulo seria aquele portador de vício tão contrário às leis ou aos princípios gerais do direito que não admite a sua convalidação, ou seja, aquele que não pode ser sanado.

Quanto ao ato anulável, esse sim permite a sua regularização, posto que dotado de vício não tão adverso ao direito, a exemplo do vício de competência.

Feita essa distinção, apresenta-se agora o conceito da corrente afirmativo-dicotômica, que prescreve aos atos nulos um prazo mais longo para serem anulados, enquanto que os atos anuláveis deverão ser anulados em um prazo mais curto.

A última corrente, qual seja, a afirmativo-unitária, ensina que, diante da ausência de prazo para se anular um ato, deverá ser adotado o prazo de 5 anos para tanto, independentemente de ser grave ou não ou vício. Cabe destacar que essa vertente é hoje a mais defendida.

Todavia, podem existir situações excepcionais em que, sob à ótica do princípio do interesse público, a decadência deve ser afastada, ordenando a aplicação da autotutela administrativa.

Como exemplo, cite-se a possibilidade de se anular um ato de nomeação de magistrado que, apesar de empossado em seu cargo por meio de concurso há mais de cinco anos, tenha se aproveitado de diploma falso de Direito para acesso ao cargo em questão. ${ }^{51}$

Ora, para a situação supracitada, quando se exigiu o diploma de Direito do concursando ao cargo de magistrado, iniciou-se o direito de a Administração anular o ato em que permitiu o seu ingresso no concurso.

O tão experimentado "caput" do art. 54 da Lei n 9.784/1999 prescreve o seguinte: "o direito da Administração de anular os atos administrativos de que

51 GOMES, Fábio Bellote. E-book. Elementos de direito administrativo. 2. ed. São Paulo: Saraiva, 2012, p. 313. 
decorram efeitos favoráveis para os destinatários decai em cinco anos, contados da data em que foram praticados, salvo comprovada má-fé". ${ }^{52}$

Observe-se que no caso fictício em questão, o concursando utilizouse de má-fé para se inscrever no certame, posto que fez uso de diploma falso, devendo então incidir no caso concreto a parte final do "caput" do art. 54 da Lei n 9.784/1999, que afasta a possibilidade de o ato ilegítimo ser acobertado pelo manto da decadência.

Entretanto, cabe salientar que o art. 54 da Lei no 9.784/1999 não atribui qualquer prazo de decadência para o ato eivado de má-fé. Estaria então a lei autorizando à Administração a anular a qualquer tempo decisão administrativa maculada por má-fé do administrado?

Os professores Sérgio Ferraz e Adilson Abreu Dallari pensam que não, defendendo que a expressão "salvo comprovada má-fé", constante da parte final do art. 54, "caput" da Lei n 9.784/1999, da maneira em que está escrita, sem qualquer limitação, é inconstitucional, haja vista que afronta o princípio da razoabilidade. ${ }^{53}$

Apesar disso, há de se convir que proceder deste modo, estabelecendo um prazo decadencial para atos praticados com má-fé, é no mínimo ameaçador ao princípio da supremacia do interesse público sobre o privado, posto que privilegia e incentiva práticas ardilosas que, em face do transcurso do prazo decadencial, agora vingam protegidas pela decadência administrativa.

Outro aspecto importante da Lei no 9.784/1999 subsiste em seu o art. 54 , $\S 1^{\circ}$ da Lei $n^{\circ} 9.784 / 1999$, o qual prescreve que "no caso de efeitos patrimoniais contínuos, o prazo de decadência contar-se-á da percepção do primeiro pagamento". 54

Os atos administrativos podem criar direitos que produzem efeitos patrimoniais que neles se exaurem ou que tenham implicações contínuas. Os primeiros são aqueles concluídos em um só ato, a exemplo do pagamento de uma ajuda de custo por mudança de domicílio do servidor. Já os de efeitos contínuos são

52 BRASIL. LEI No 9.784, de 20 de janeiro de 1999. Regula o processo administrativo no âmbito da Administração Pública Federal. Disponível em: <http://www.planalto.gov.br/ccivil 03/leis/L9784.htm>. Acesso em: 03 fev. 2018.

53 FERRAZ, Sérgio, DALLARI, Adilson Abreu. Processo administrativo. 3. ed. São Paulo: Malheiros Editores, 2012, p. 268.

54 BRASIL. LEI N ${ }^{\circ}$ 9.784, de 20 de janeiro de 1999. Op. cit. 
os que se prolongam no tempo, como o pagamento de adicional por tempo de serviço, que é devido ao servidor que lhe detém o direito todo mês.

O professor José dos Santos Carvalho Filho leciona que o prazo decadencial mencionado no art. $54 \S 1^{\circ}$ da Lei $n^{\circ} 9.784 / 1999$, dirigido aos atos com efeitos patrimoniais contínuos, é tipicamente decadencial, e visa resguardar àquele administrado que vem recebendo determinada vantagem por mais de cinco anos, ininterruptamente. ${ }^{55}$

Defende ainda esse doutrinador que não se pode confundir o prazo para a Administração anular um ato que conferiu efeitos benéficos ao administrado, que é decadencial, com aquele prazo para este exercer a sua pretensão, que é prescricional, constante do Decreto $n^{\circ}$ 20.910/1932.

Portanto, se o ato produz efeitos patrimoniais de caráter continuado para o administrado, a cada parcela individual devida ressurge para ele a pretensão a determinado direito. ${ }^{56}$

Percebe-se, então, que a Administração pode se valer desse entendimento sobre os atos que concederam benefícios patrimoniais de efeitos continuados, principalmente quando esta age para corrigir um ato concedido indevidamente, posto que aqui ela não pretende anulá-lo ou suprimi-lo, mas sim corrigi-lo.

Como exemplo, imagine que um servidor receba um adicional por tempo de serviço no percentual $16 \%$. Contudo, após mais de cinco anos recebendo tal vantagem, descobre-se que o percentual correto é de 15\%. Ora, como aqui a Administração não pretende anular o ato e sim ajustá-lo, constata-se então estar diante de um prazo não ligado ao próprio direito em si, portanto prescricional, que se renova mês a mês, a cada pagamento.

Esse juízo pode ser ratificado da ementa de decisão do STJ abaixo transcrita ${ }^{57}$, litteris:

ADMINISTRATIVO E PROCESSUAL CIVIL. AGRAVO REGIMENTAL NO AGRAVO EM RECURSO ESPECIAL. SUBTRAÇÃO SALARIAL

55 CARVALHO FILHO, José dos Santos. E-book. Processo administrativo federal: comentários à lei no 9.784/1999, de 29.1.1999. 5. ed. rev., ampl. e atual. até 31.3.2013. São Paulo: Atlas, 2013, pp. 275-276.

56 Idem, p. 276.

57 SUPERIOR TRIBUNAL DE JUSTIÇA. Agravo Regimental no Agravo em Recurso Especial $\mathbf{n}^{\circ}$ 129.718 - PE. Relator: Olindo Menezes. Pesquisa de Jurisprudência, Acórdãos, Brasília, 10 nov. 2015. Disponível em: <http://www.stj.jus.br/SCON>. Acesso em: 03 fev. 2018. 
INDEVIDA. PRESCRIÇÃO DO FUNDO DE DIREITO. INOCORRÊNCIA. TERMO INICIAL. PRESTAÇÕES DE TRATO SUCESSIVO. SÚMULA 85/STJ. RAZÕES NÃ̃O IMPUGNADAS ESPECIFICAMENTE. APLICAÇÃO PARCIAL DA SÚMULA 182/STJ. AGRAVO REGIMENTAL DESPROVIDO. 1. Consoante a jurisprudência do STJ, a redução de benefícios funcionais configura relação jurídica de trato sucessivo - supressão de valores ocorrida mês a mês - nos moldes do que dispõe a súmula $85 /$ STJ, o que afasta a tese de prescrição do fundo de direito. 2. Não se conhece de tópicos carecedores de impugnação específica, mediante incidência do teor da súmula 182/STJ (parcialmente), em homenagem ao princípio da dialeticidade recursal. 3. Agravo regimental desprovido.

O entendimento acima exibido parece o mais ajustado, haja vista que oferece tratamento isonômico entre a Administração e o administrado, em face de situação jurídica idêntica.

Quanto ao já mencionado prazo prescricional para o administrado exercer a sua pretensão de ação contra a fazenda pública, este é também de cinco anos, conforme disposto no Decreto $n^{\circ} 20.910 / 1932$, mais precisamente em seu art. $1^{\circ}$.

Cabe salientar que existe também um prazo decadencial para que o administrado reclame o seu direito junto à Administração. Esse prazo está exposto no art. $6^{\circ}$ do Decreto-Lei $n^{\circ} 20.910 / 1932^{58}$, cuja transcrição se faz a seguir, in verbis: "Art. $6^{\circ} \mathrm{O}$ direito à reclamação administrativa, que não tiver prazo fixado em disposição de lei para ser formulada, prescreve em um ano a contar da data do ato ou fato do qual a mesma se originar".

Observe-se que existe impropriedade técnica no dispositivo acima ao se referir à prescrição e não à decadência. Isso porque tal artigo versa sobre um direito do administrado e não da pretensão em si, como bem orientam os professores Sérgio Ferraz e Adilson Abreu Dallari. ${ }^{59}$

Ressalte-se que tal prazo de um ano conferido ao administrado seria inapropriado e não isonômico caso ele fulminasse seu direito material, posto que muito distante do prazo de cinco anos conferido à Administração para anular um ato, conforme prescrito no já citado art. 54 da Lei nº 9.784/1999.

58 BRASIL. DECRETO-LEI No 20.912, de 6 de janeiro de 1932. Regula a prescrição quinquenal. Disponível em:<http://www.planalto.gov.br/ccivil 03/decreto/Antigos/D20910.htm>. Acesso em: 04 fev. 2018.

59 FERRAZ, Sérgio, DALLARI, Adilson Abreu. Processo administrativo. 3. ed. São Paulo: Malheiros Editores, 2012, p. 267. 
Devido a isso, defende-se aqui que seja atribuído ao administrado, quanto à extinção do seu direito material, o mesmo prazo decadencial de cinco anos conferido à Administração pelo art. 54 da Lei no 9.784/1999, por entender que o curto lapso temporal de um ano ofenderia aos princípios constitucionais da ampla defesa e do contraditório.

Importante mencionar ainda que, segundo dispõe o art. $54, \S 2^{\circ}$ da Lei $n^{\circ}$ 9.784/1999, configura-se como exercício do direito de anular o ato por sua invalidade qualquer medida tomada pela Administração para tanto. ${ }^{60}$

Entretanto, entende-se que a medida da Administração tomada para anular o ato, capaz de obstar o transcurso do prazo decadencial, deve proporcionar ao administrado o direito à ampla defesa e ao contraditório.

Assim, não pode obstar o transcurso do prazo decadencial a simples instauração de processo administrativo do qual o interessado não tenha tomado ciência. Nesse sentido, segue transcrição do item 7 da ementa do Mandado de Segurança $\mathrm{n}^{\circ}$ 19579/DF do ST J61, in verbis:

$[\ldots]$

7. O exercício do direito do Poder Público anular as anistias políticas exige a presença de elementos para o reconhecimento de sua validade. Além disso, esta Corte Superior já proclamou o entendimento no sentido de que as recomendações exaradas pelo Tribunal de Contas da União e as NOTAS AGU/JD-10/2003 e AGU/JD-1/2006, "não se enquadram na definição de "medida de autoridade administrativa": MS 16.609/DF, 1a Seção, Rel. Min. Arnaldo Esteves Lima, DJe 22.6.12; MS 17.371/DF, $1^{\text {a }}$ Seção, Rel. Min. Arnaldo Esteves Lima, DJe 10.8.12. Por outro lado, o procedimento tendente a anular $\mathrm{o}$ ato administrativo exige, necessariamente, sob pena de grave violação aos princípios do contraditório, ampla defesa e devido processo legal, a cientificação individual do beneficiário do ato impugnado (art. 66 da Lei 9.784/99), circunstância não comprovada pelo Poder Público nas referidas notas, apontadas como medidas impugnativas praticadas pela autoridade administrativa das anistias políticas concedidas aos militares.[...].

Compete também ressaltar relevante discussão doutrinária e jurisprudencial que existia, no que diz respeito à possibilidade de ser aplicado o prazo decadencial do art. 54 da Lei no 9.784/1999 aos atos administrativos anteriores à sua

60 BRASIL. LEI № 9.784, de 20 de janeiro de 1999. Regula o processo administrativo no âmbito da Administração Pública Federal. Disponível em: <http://www.planalto.gov.br/ccivil 03/leisLL9784.htm>. Acesso em: 04 fev. 2018.

61 SUPERIOR TRIBUNAL DE JUSTIÇA. Mandado de Segurança $\mathbf{n}^{\circ} 19.579$ - DF. Relator: Mauro Campbell Marques. Pesquisa de Jurisprudência, Acórdãos, Brasília, 06 nov. 2013. Disponível em: <http://www.sti.jus.br/SCON/jurisprudencia>. Acesso em: 04 fev. 2018. 
vigência. Atualmente, a contenda já foi resolvida pela jurisprudência, no sentido de que o prazo de cinco anos do art. 54 da Lei $n^{\circ}$ 9.784/1999 somente começa a correr após a sua vigência, mesmo que o ato tenha sido praticado anteriormente. $A$ corroborar esse entendimento, aproveita-se para transcrever ementa dos Embargos de Declaração no Recurso Ordinário n RMS 30576 ED/DF, do Supremo Tribunal Federal $^{62}$, ipsis litteris:

EMENTA Embargos de declaração em recurso ordinário em mandado de segurança. Decisão monocrática. Conversão em agravo regimental. Causa interruptiva de decadência administrativa devidamente prevista em lei. Termo inicial de contagem do prazo decadencial para a Administração Pública anular atos praticados antes da edição da Lei $n^{\circ}$ 9.784/1999. Aplicação do entendimento firmado no Supremo Tribunal Federal. Alegado afastamento de dispositivo legal não verificado. Ausência de violação da cláusula de reserva de plenário. Agravo não provido. 1. Descabida a alegação de criação jurisprudencial de causa interruptiva de decadência não prevista em lei, pois é a própria Lei $n^{\circ} 9.784 / 1999$ que prevê, em seu art. $54, \S 2^{\circ}$, que qualquer medida de autoridade administrativa que impugne a validade de um ato já constitui o exercício do direito de anulá-lo. 2. Relativamente aos atos praticados antes da edição da Lei $\mathrm{n}^{\circ}$ 9.784/1999, é aplicável o prazo decadencial de cinco anos para a Administração anulá-los, contados a partir da vigência dessa lei. Precedentes do STF. 3. É competente o relator para, monocraticamente, negar seguimento a recurso manifestamente inadmissível, improcedente ou em desacordo com a jurisprudência do Tribunal. Artigo $21, \S 1^{\circ}$, do Regimento Interno do Supremo Tribunal Federal. 4. Agravo não provido.

Postas então todas essas considerações e características sobre a preclusão, prescrição e decadência, cabe em sequência trabalhar sobre a possibilidade ou não de a Administração, ou os Tribunais de Contas, modificarem ou anularem uma decisão administrativa, em face do transcurso de largo lapso temporal, mais precisamente, passados mais de cinco anos da decisão.

62 SUPREMO TRIBUNAL FEDERAL. Embargos de Declaração no Recurso Ordinário $\mathbf{n}^{\circ}$ RMS 30576 ED/DF. Relator: Dias Toffoli. Pesquisa de Jurisprudência, Acórdãos, Brasília, 06 nov.2013. Disponível em: <http://www.stf.jus.br/portal/jurisprudencia> $>$. Acesso em: 04 fev. 2018. 


\section{CAPÍTULO 3: A ALTERAÇÃO DA DECISÃO ADMINISTRATIVA EM FACE DO TRANSCURSO DE LARGO LAPSO TEMPORAL}

Concluindo o presente trabalho, esse capítulo irá discorrer sobre a alteração da decisão administrativa após o decurso de determinado período, sob o enfoque do controle externo dos Tribunais de Contas.

Inicialmente, visando melhor contextualizar o leitor sobre o assunto, será aqui trabalhada a então denominada coisa julgada administrativa, explicando os seus contornos mais relevantes para a condução de um juízo jurídico sobre os efeitos do transcurso do tempo sobre uma decisão da Administração.

Serão destacadas também as principais posições doutrinárias e jurisprudenciais dos tribunais superiores sobre a coisa julgada administrativa, com a intenção de demonstrar quando específica decisão administrativa pode se tornar imutável para o gestor da Administração.

Após, irá se discorrer sobre a posição do controle externo exercido pelos tribunais de contas do Brasil, no que tange ao alcance de uma decisão administrativa, quando do exame dos atos de aposentadoria realizado pelas diversas cortes de contas nacionais.

Por fim, esse trabalho apresentará as nuances jurídicas sobre a contagem do prazo decadencial para o alcance por parte dos Tribunais de Contas de uma decisão da Administração, e os seus respectivos reflexos sobre os atos decisórios dos gestores públicos.

\subsection{Coisa julgada administrativa}

O processo, seja ela cível, penal ou administrativo, tem de ter uma duração razoável entre o seu início e o seu fim, haja vista que a sua permanência descomedida no tempo pode entregar o bem da vida desejado no litígio sem mais qualquer utilidade.

Além disso, é necessário que, após passado algum tempo, o processo administrativo, bem como a decisão nele contida, torne-se estável, em nome do princípio da segurança jurídica, já estudado nos capítulos anteriores. 
Dessas necessidades, surge então o conceito de coisa julgada administrativa, responsável por tornar a decisão juridicamente assente, pelo menos no âmbito da Administração Pública.

Cabe salientar que a expressão "coisa julgada administrativa" é controvertida, haja vista que, a princípio, somente a atividade jurisdicional poderia produzir coisa julgada.

A professora Maria Sylvia Zanella Di Pietro afirma que a coisa julgada administrativa é conceito tipicamente oriundo do direito processual cível e penal, que foi adaptado para o direito administrativo, por meio de doutrinadores que não enxergam uma distinção de fundo entre a administração e a atividade de jurisdição, existindo uma diferença somente formal. ${ }^{63}$

Apesar disso, essa ilustre doutrinadora segue afirmando que tal conceito não pode ser simplesmente conduzido de um ramo do direito no qual possui pleno fundamento para um outro em que não se justifica, posto que na atividade jurisdicional, onde o conceito de coisa julgada é regularmente aplicado, o Poder Judiciário desempenha um papel estranho à lide, distintamente da função administrativa, em que a Administração é parte naquilo em que está decidindo. ${ }^{64}$

Ademais, uma decisão administrativa sempre poderá ter alguns de seus aspectos submetidos à apreciação do Poder Judiciário. Assim, a expressão "coisa julgada administrativa", em uma primeira visão, poderia aparentar colisão com o princípio da jurisdição única, entalhado no art. $5^{\circ}$, inc. XXXV da Constituição Federal, que assim prescreve, litteris: "a lei não excluirá da apreciação do Poder Judiciário lesão ou ameaça a direito". 65

Os professores Sérgio Ferraz e Adilson Abreu Dallari defendem com veemência sobre a possibilidade de se falar em coisa julgada administrativa, posto que tal expressão não estaria relacionada com a possibilidade ou não de revisão do ato administrativo pelo Poder Judiciário, mas sim na inexequibilidade de reforma do ato ou da decisão administrativa por parte da Administração, seja de ofício ou por provocação, após o devido transcurso do processo. ${ }^{66}$

63 DI PIETRO, Maria Sylvia Zanella. Direito administrativo. 28. ed. São Paulo: Atlas, 2015, p. 889.

64 Idem, p. 890.

65 BRASIL. CONSTITUIÇÃO FEDERAL, de 5 de outubro de 1988. Constituição da República Federativa do Brasil de 1988. Disponível em: <http://www.planalto.gov.br/ccivil 03/constituicao/constituicaocompilado.htm>. Acesso em: 10 jul. 2018.

66 FERRAZ, Sérgio, DALLARI, Adilson Abreu. Processo administrativo. 3. ed. São Paulo: Malheiros Editores, 2012, p. 71. 
Todavia, para o presente estudo, essa discussão doutrinária se mostra irrelevante, sendo necessário aqui apenas trabalhar com a coisa julgada no âmbito do direito administrativo, correspondendo àquela decisão que se tornou imutável exclusivamente para a Administração.

Ao proferir uma decisão dentro do processo administrativo, considerando que esse se submeteu ao crivo do contraditório e da ampla defesa, expõe-se um juízo sobre determinado litígio entre à parte interessada e o Estado, sendo que esse entendimento não pode ser errático e modificável a qualquer momento, posto que isto geraria instabilidade e insegurança nas relações jurídicas.

Tão relevante a preservação da segurança jurídica que o legislador resolver deixar isso explícito na lei de processo administrativo da administração federal, implicando na vedação à aplicação retroativa de novo entendimento, conforme prescrito no inc. XIII, art. $2^{\circ}$ da Lei $n^{\circ}$ 9.784/1999.

Cabe salientar que, caso seja identificado ato ou atos ilegais dentro do processo administrativo, a Administração estaria autorizada como regra a anular a decisão administrativa, segundo impõe o art. 53 da Lei n 9.784/199967, que reza: "A Administração deve anular seus próprios atos, quando eivados de vício de legalidade, e pode revogá-los por motivo de conveniência ou oportunidade, respeitados os direitos adquiridos".

Conquanto o dispositivo acima prescreva ser um dever por parte do Estado-administrador anular os atos que estejam assinalados com a mancha da ilegalidade, os professores Sérgio Ferraz e Adilson Abreu Dallari afirmam que a anulação do ato não poderá acontecer, quando dela possa decorrer lesões ou ameaças a direitos de terceiros que se originaram de uma decisão administrativa. ${ }^{68}$

Além disso, relevante se faz apontar que os institutos da preclusão administrativa, da prescrição e da decadência, todos já trabalhados nesse trabalho, são também capazes de tornar a decisão administrativa imutável e, portanto, alcançar assim a coisa julgada administrativa.

Quanto à preclusão administrativa, cabe ainda ressaltar, no que tange à possibilidade de se modificar uma decisão por meio de um recurso, que a própria

67 BRASIL. LEI NN 9.784, de 20 de janeiro de 1999. Regula o processo administrativo no âmbito da Administração Pública Federal. Disponível em: <http://http://www.planalto.gov.br/ccivil 03/leis/L9784.htm>. Acesso em: 11 jul. 2018.

68 FERRAZ, Sérgio, DALLARI, Adilson Abreu. Processo administrativo. 3. ed. São Paulo: Malheiros Editores, 2012, p. 71. 
Lei $n^{\circ}$ 9.784/1999, em seu art. 6369, traz um elenco de situações em que esse expediente não será conhecido, quais sejam: a) recurso apresentado fora do prazo; b) recurso apresentado perante órgão incompetente; c) recurso interposto por alguém incompetente; d) e, por fim, recurso aviado após esgotada a esfera administrativa.

Frise-se mais uma vez que a supracitada impossibilidade de se modificar a decisão administrativa somente ocorrerá dentro da Administração e, portanto, é relativa, haja vista que, caso o litigante tenha o seu direito violado dentro de um processo administrativo, mesmo que não haja mais qualquer recurso nesse âmbito, sempre lhe caberá se socorrer do Poder Judiciário, sendo que, para isso, não possui qualquer relevância o fato de o ato ou da decisão administrativa já estar pacificada nessa esfera, conforme destaca o ilustre professor Carvalho Filho. ${ }^{70}$

A coisa julgada administrativa também se mostra relevante quando do estudo da aplicação das sanções disciplinares. Isso porque a coisa julgada administrativa oferece uma proteção ao não permitir que determinada sanção seja dirigida a uma mesma situação fática mais de uma vez, o que é conhecido como o princípio do non bis in idem.

Assim, dentro de um processo disciplinar que chegou ao fim, aplicando uma sanção ao administrado, e, consequentemente, alcançando a coisa julgada administrativa, não mais poderá ser aberto um novo processo que tenha um mesmo fim, impedindo que a parte atingida seja submetida a uma incerteza eterna. ${ }^{71}$

Feitas essas basilares considerações sobre a coisa julgada administrativa, que torna a decisão ou ato administrativo imutável dentro da própria Administração, dando destaque para os seus respectivos efeitos, passa-se agora a tecer breves comentários sobre o que orienta a jurisprudência dos tribunais superiores sobre esse tema.

69 BRASIL. LEI No 9.784, de 20 de janeiro de 1999. Regula o processo administrativo no âmbito da Administração Pública Federal. Disponível em: <http://http://www.planalto.gov.br/ccivil 03/leis/L9784.htm>. Acesso em: 11 jul. 2018.

70 CARVALHO FILHO, José dos Santos. E-book. Processo administrativo federal: comentários à lei no 9.784/1999, de 29.1.1999. 5. ed. rev., ampl. e atual. até 31.3.2013. São Paulo: Atlas, 2013, p. 322.

71 NOHARA, Irene Patrícia, MARRARA, Thiago. E-book. Processo administrativo: lei no 9.784/99 comentada. São Paulo: Atlas, 2009, p. 450. 


\subsection{Análise jurisprudencial quanto à coisa julgada administrativa}

A jurisprudência pátria dos tribunais superiores há tempos apresenta decisões sobre a coisa julgada administrativa, principalmente no que diz respeito aos processos que envolvem a administração tributária.

O alcance da coisa julgada administrativa, quando o assunto abarca o lançamento de débitos fiscais, é tão abrangente que pode até mesmo ser motivo para se propor uma revisão criminal, conforme se vê do excerto de parte da ementa a seguir, extraído de julgado do sítio do Superior Tribunal de Justiça ${ }^{72}$, litteris:

2. A superveniência de coisa julgada administrativa, excluindo lançamento de dívida fiscal que gerara, também, ação penal contra o embargante constitui possível fundamento para o ajuizamento de uma revisão criminal. Mas, ainda que tal fato novo pudesse ser apreciado em sede de habeas corpus, remanesce a incompetência constitucional da Terceira Seção desta Corte para conceder habeas corpus contra acórdão de Turma do próprio tribunal.

Especificamente quanto ao Direito Administrativo, a jurisprudência do Superior Tribunal de Justiça caminha também no sentido de que, alcançada a coisa julgada administrativa, esta tem o poder de tornar a decisão administrativa irretocável, mesmo que, posteriormente, seja constatada qualquer ilegalidade em algum ato que tenha originado tal decisão. Nesse sentido, aproveita-se para transcrever importante julgado do STJ ${ }^{73}$, in verbis:

1. Não ampara a jurisprudência cristalizada na Súmula $n^{\circ} 473 / S T F$, nem há previsão legal que possibilite à Administração Pública, findo o julgamento administrativo, rever o que foi por ela decidido, ainda que a pedido, para corrigir suposta ilegalidade, quando esgotados os recursos administrativos cabíveis.

Desse modo, conforme o entendimento do Superior Tribunal de Justiça acima esposado, terminado todo o trâmite do processo administrativo, não

72 SUPERIOR TRIBUNAL DE JUSTIÇA. Embargos de Declaração no Agravo Regimental nos Embargos de Divergência em Recurso Especial n 2012/0069215-2. Relator: Reynaldo Soares da Fonseca. Pesquisa de Jurisprudência, Acórdãos, Brasília, 02 dez. 2016. Disponível em: $<$ http://www.stj.jus.br/SCON/jurisprudencia/toc.jsp?livre=\%22coisa+julgada+administrativa $\% 22+e+$ fiscal\&\&b=ACOR\&thesaurus=JURIDICO\&p=true>. Acesso em: 16 jul. 2018.

73 SUPERIOR TRIBUNAL DE JUSTIÇA. Agravo Interno no Recurso em Mandado de Segurança n 2016/0121257-6. Relator: Mauro Campbell Marques. Pesquisa de Jurisprudência, Acórdãos, Brasília, 03 out. 2016. Disponível em: <http://www.stj.jus.br/SCON/jurisprudencia/toc.jsp?livre $=\% 22$ coisa + julgada + administrativa $\% 22 \& \& b=A C O R \&$ thesaurus=JURIDICO\&p=true $>$.

Acesso em: 16 jul. 2018. 
mais existindo a possibilidade de se interpor qualquer recurso na esfera da Administração, o processo se encontra finalizado.

Quanto à possibilidade de apreciação por parte do Poder Judiciário da coisa julgada administrativa, o Supremo Tribunal Federal tem esclarecedora súmula sobre o tema, qual seja, a Súmula $n^{\circ} 473^{74}$, a qual, em sua parte final, prescreve que, mesmo cabendo à Administração anular de ofício os atos eivados de vícios que os tornam ilegais, em todos os casos será permitida a apreciação judicial.

Essa súmula da Suprema Corte Constitucional deixou assente o entendimento de que a coisa julgada administrativa somente pode existir dentro da própria Administração, não alcançando o poder de revisão ou de apreciação do ato administrativo por parte do Judiciário.

Cabe ressaltar ainda que, a despeito de ser possível o Poder Judiciário apreciar a decisão alcançada pela coisa julgada administrativa, essa apreciação não poderá agravar, em regra, a situação daquele que solicita o seu socorro ao recorrer, sendo tal princípio reconhecido como o do "non reformatio in pejus". Nesse sentido, aproveita-se para transcrever a seguir excerto da ementa referente aos autos do REsp $1346271 / \mathrm{RS}^{75}$, in verbis:

4. A jurisprudência desta Corte é pela incidência de juros compensatórios, em desapropriação indireta, a partir da ocupação efetiva do bem pelo ente público, conforme entendimento expresso na Súmula 69/STJ. O acórdão local entendeu pela incidência a partir da propositura da ação, o que, apesar de contrariar tal posição, é favorável ao recorrente, devendo ser mantido o aresto recorrido, em virtude da proibição da reformatio in pejus.

Entretanto, saliente-se que no decorrer do processo administrativo, caso ainda não tenha sido alcançada a coisa julgada administrativa, à Administração é permitido, ao apreciar um recurso, agravar a situação do administrado recorrente, nos termos do art. 64, par. único da Lei $n^{0} 9.784 / 1999^{76}$, desde que ele seja

74 SUPREMO TRIBUNAL FEDERAL. Súmula n. 473. Brasília, 03 dez. 1969. Disponível em: $<$ http://www.stf.jus.br/portal/jurisprudencia/listarJurisprudencia.asp?s1=473.NUME.\%20NAO\%20S. FLSV.\&base=baseSumulas $>$. Acesso em: 17 jul. 2018.

75 SUPERIOR TRIBUNAL DE JUSTIÇA. Recurso Especial $n^{\circ}$ 1346271/RS. Relator: OG FERNANDES. Pesquisa de Jurisprudência, Acórdãos, Brasília, 26 fev. 2018. Disponível em: $<$ http://www.stj.jus.br/SCON/jurisprudencia/toc.jsp?livre=\%22administrativo $\% 22+\mathrm{e}+\% 22$ reformatio + inpejus\%22\&\&b=ACOR\&thesaurus=JURIDICO\&p=true >. Acesso em: 17 jul. 2018.

76 BRASIL. LEI No 9.784, de 20 de janeiro de 1999. Regula o processo administrativo no âmbito da Administração Pública Federal. Disponível em: <http://www.planalto.gov.br/ccivil 03/leis/L9784.htm>. Acesso em: 17 jul. 2018. 
cientificado para apresentar sua defesa mirando afastar a nova decisão que agravará a sua situação, em homenagem aos princípios da ampla defesa e contraditório.

Ainda, relevante também registrar que alguns vícios jamais permitem que o processo alcance a coisa julgada administrativa. Como exemplo, cite-se a acumulação indevida de cargos públicos, em desacordo com as regras expostas na Constituição Federal, cujo vício é tão afrontoso que não se pode convalidá-lo pelo transcurso do tempo, conforme entendimento do Superior Tribunal de Justiça, que se extrai de parte da ementa referente aos autos do Agravo Regimental nos Embargos de Declaração no Recurso em Mandado de Segurança $n^{\circ} 2008 / 0286249-3^{77}$, in verbis:

1. Conforme a jurisprudência do Superior Tribunal de Justiça, não há falar em direito adquirido à cumulação de cargos públicos nos casos em que estes não estão previstos na exceção constitucional, porquanto tal vício não se convalida com o decurso do tempo. Não há que se alegar, pois, decadência, prescrição ou coisa julgada administrativa.

2. A acumulação ilegal de cargos públicos, expressamente vedada pelo art. 37, XVI, da Constituição Federal, caracteriza uma situação que se protrai no tempo, motivo pelo qual é passível de ser investigada pela Administração a qualquer tempo, a teor do que dispõe o art. 133, caput, da Lei 8.112/90 (MS 20148/DF, Rel. Ministro Arnaldo Esteves Lima, Primeira Seção, DJe 18/9/2013).

3. Agravo regimental improvido.

Ao compulsar o art. 133 da Lei $n^{\circ}$ 8.112/199078, mencionado pela decisão supra, constata-se a sua determinação no sentido de que, verificada a qualquer tempo pela Administração a acumulação ilegal de cargos, empregos ou funções, essa tomará as devidas providências para sanar o vício, notificando o servidor para optar em qual cargo deseja permanecer, ou, na ausência de opção, promover a instauração de procedimento sumário para a devida regularização.

Essa opção do legislador, seguida da interpretação do Superior Tribunal de Justiça no mesmo caminho, vedando o alcance da coisa julgada administrativa para as situações de acumulação irregular de cargos públicos não poderia ser de melhor agrado ao interesse público.

77 SUPERIOR TRIBUNAL DE JUSTIÇA. Agravo Regimental nos Embargos de Declaração no Recurso em Mandado de Segurança $n^{\circ}$ 2008/0286249-3. Relator: NEFI CORDEIRO. Pesquisa de Jurisprudência, Acórdãos, Brasília, 05 nov. 2015. Disponível em: $<$ http://www.stj.jus.br/SCON/jurisprudencia/toc.jsp?livre $=\% 22$ coisa+julgada+administrativa $\% 22 \& \& b$ $=$ ACOR\&thesaurus=JURIDICO\&p=true $>$. Acesso em: 18 jul. 2018.

78 BRASIL. LEI No 8.112, de 11 de dezembro de 1990. Dispõe sobre o regime jurídico dos servidores públicos civis da União, das autarquias e das fundações públicas federais. Disponível em: <http://www.planalto.gov.br/ccivil 03/leis/L8112cons.htm>. Acesso em: 18 jul. 2018 
Isso porque permitir a convalidação de acumulação inconstitucional de cargos públicos, sob o argumento da coisa julgada administrativa, é incentivar uma prática que não rara as vezes prejudica a regular e eficiente prestação do serviço público pelo agente do Estado; esse deve concentrar os seus esforços no bom desempenho de suas tarefas diárias, sendo que a jornada de trabalho excessiva pode provocar declínio na qualidade do trabalho apresentado, motivo pelo qual a permissão para se acumular cargos públicos deve continuar sendo uma exceção.

Deixa-se de apresentar nesse momento a jurisprudência da Suprema Corte Constitucional, no que diz respeito à abrangência da coisa julgada administrativa perante as decisões dos Tribunais de Contas, ao exercerem a sua missão constitucional de controle externo, haja vista que o tema será destacado na parte final desse trabalho, no próximo subitem, como arremate final do presente estudo.

\subsection{O Controle das decisões administrativas pelos tribunais de contas}

\subsubsection{Disposições constitucionais sobre os tribunais de contas}

Os tribunais de contas possuem a relevante missão constitucional de auxiliar o Poder Legislativo no exercício do controle externo das contas públicas, por meio de fiscalização contábil, financeira, orçamentária, patrimonial e operacional dos entes federados, conforme se extrai da leitura conjunta dos artigos 70 e 71 da Constituição Federal. ${ }^{79}$

A nossa Carta Magna, em seu art. 71, traz as atribuições pertencentes ao Tribunal de Contas da União, contudo, essas atividades podem também ser exercidas pelos outros tribunais de contas dos diversos entes federados, como assim dispõe o art. 75 da Constituição Federal. ${ }^{80}$

Relevante destacar que o auxílio prestado pelo Tribunal de Contas ao Poder Legislativo mencionado pela Constituição Federal é no sentido de prestar uma função e não de assessorar o Poder Legislativo, posto que as cortes de contas não

\footnotetext{
79 BRASIL. CONSTITUIÇÃO FEDERAL, de 5 de outubro de 1988. Constituição da República Federativa do Brasil de 1988. Disponível em: <http://www.planalto.gov.br/ccivil 03/constituicaoIconstituicaocompilado.htm>. Acesso em: 19 jul. 2018.

80 Idem.
} 
são subjugadas por nenhum dos poderes, como bem ressalta o professor Jorge Ulisses Jacoby Fernandes. ${ }^{81}$

Ademais, os tribunais de contas, no desempenho de suas atribuições constitucionais, são independentes, segundo ensinava o saudoso professor Hely Lopes Meirelles. ${ }^{82}$

O trabalho de fiscalização desempenhado pelas cortes de contas do nosso país é então denominado pela própria Constituição Federal de controle externo. Esse controle externo é distinto dos demais tipos de controle. Ele não é jurisdicional ou judicial, posto que não produz coisa julgada no sentido estrito, sendo que a decisão tomada pelos tribunais de contas poderá ser revista em parte pelo Poder Judiciário.

Ainda, esse controle também se distingue do controle administrativo. O controle administrativo é aquele realizado pela própria Administração, quando, por exemplo, esta anula um ato ilegal ou revoga uma decisão por conveniência e oportunidade. O controle externo não está na estrutura da própria Administração ou do próprio ente.

Cabe ainda distinguir o controle externo do controle interno. O controle interno também está encravado no caput do art. 70 da Constituição Federal ${ }^{83}$, e também tem o encargo de realizar a fiscalização contábil, operacional, financeira, orçamentária, e patrimonial, porém, ele atua dentro de um sistema originário do próprio ente que criou o ato, distintamente do controle externo, que é independente à administração da unidade da federação, seja a União, os Estados, DF ou os municípios.

Essa fiscalização dos tribunais de contas, então denominada de controle externo, realizada pelas cortes de contas das diversas unidades da federação, pode ser efetivada por meio de auditorias, de inspeções, de levantamentos, de monitoramentos, dentre outras técnicas de fiscalização, então produtoras de decisões dirigidas à Administração.

81 JACOBY FERNANDES, Jorge Ulisses. Tribunais de contas do Brasil: jurisdição e competência. 4. ed. Belo Horizonte: Fórum, 2016, p. 141.

82 MEIRELLES, Hely Lopes; ALEIXO, Délcio Balestero; BURLE FILHO, José Emmanuel. Direito administrativo brasileiro.41. ed. São Paulo: Malheiros Editores, 2014, p. 825.

83 BRASIL. CONSTITUIÇÃO FEDERAL, de 5 de outubro de 1988. Constituição da República Federativa do Brasil de 1988. Disponível em: <http://www.planalto.gov.br/ccivil 03/constituicao/constituicaocompilado.htm>. Acesso em: 19 jul. 2018. 
Uma decisão dessas, proferida pelas cortes de contas, pode também imputar débito ou multa ao gestor da despesa pública, sendo que tal decisão terá eficácia de título executivo, nos termos indicados pelo art. $71, \S 3^{\circ}$ da CF.$^{84}$

Atualmente, é de se observar no Brasil que as atividades realizadas pelos tribunais de contas não se resumem apenas ao mero controle contábil, financeiro e orçamentário da despesa pública, mas sim em auditorias e fiscalizações que realmente contribuem para o aperfeiçoamento da máquina pública do país.

A atuação do Tribunal de Contas é relevante e de grande responsabilidade, haja vista que a corte de contas pode determinar ao gestor a sustação de um ato administrativo e, caso esse não atenda, o próprio Tribunal de Contas poderá sustar o ato, comunicando a decisão à Câmara dos Deputados e ao Senado Federal, para o caso que envolvam recursos da União, nos termos do que está prescrito no art. $71, \mathrm{X}$ da CF. 85

Contratos entre a Administração e particulares, visando os mais diversos fins, envolvendo enormes recursos públicos, são realizados diariamente, sendo que os tribunais de contas também podem fiscalizá-los, e, não raras as vezes, podem solicitar que o gestor os suste. Todavia, caso não haja a sustação do contrato por parte do gestor, quem poderá fazê-lo nesse caso será o Congresso Nacional, por meio de Decreto Legislativo, requerendo ao Poder Executivo à adoção de medidas de imediato, conforme indica o art. $71, \S 1^{\circ}$ da CF.86

Dessa forma, qualquer decisão administrativa que acarrete uma despesa pública pode ser apreciada e fiscalizada pelos tribunais de contas, sendo que, normalmente, esse controle é realizado concomitantemente ou posteriormente ao ato de despesa produzido e quase nunca anteriormente ao ato, a não ser em situações muito especiais, como exame por parte das cortes de contas de editais de licitação.

No entanto, para o presente objetivo, torna-se mais relevante destacar a forma de fiscalização mencionada no art. 71 , III da Constituição Federa| ${ }^{87}$, que se refere à apreciação por parte dos tribunais de contas, para fins de registro, das

84 BRASIL. CONSTITUIÇÃO FEDERAL, de 5 de outubro de 1988. Constituição da República Federativa do Brasil de 1988. Disponível em: <http://www.planalto.gov.br/ccivil 03/constituicao/$85 \frac{\text { ldem. }}{\text { Idem. }}$

86 Ibidem.

87 Ibidem. 
concessões de aposentadorias, com exceção das melhorias posteriores que não modifiquem o fundamento legal do ato concessório, posto que aqui poderá ser dado enfoque na produção da coisa julgada administrativa e o seu devido alcance para as cortes de contas, como se verá a seguir.

\subsubsection{A coisa julgada administrativa e os tribunais de contas}

Terminado o processo no âmbito administrativo, não cabendo mais qualquer recurso nessa esfera, atinge-se a coisa julgada para a Administração.

No entanto, mesmo que não mais seja possível o alcance da decisão por parte do gestor público, nem sempre esse mesmo efeito será atribuído às Cortes de Contas brasileiras.

Dessa forma, faz-se necessário inicialmente retomar o assunto sobre o instituto da decadência administrativa, mas agora sob outro enfoque, qual seja, aquele dirigido aos tribunais de contas brasileiros.

A decadência, nos dizeres do professor Carlos Roberto Gonçalves, começa a correr no momento em que o direito nasce. ${ }^{88}$

Ademais, é por meio dela que se extirpa o direito de a fazenda pública constituir o crédito tributário, conforme lecionam os professores Ítalo Romano Eduardo e Jeane Tavares Aragão Eduardo ${ }^{89}$, conceito relevante quando se está analisando aposentadorias, posto que as contribuições para a aposentação são uma espécie de tributo.

$\mathrm{E}$, após originar-se o direito, o grande transcurso posterior de tempo deve por fim à relação jurídica anteriormente iniciada, no intuito de evitar a instabilidade social ${ }^{90}$, como já estudado em capítulos anteriores desse trabalho.

No âmbito da Administração Pública, como já visto previamente, passados 5 anos da origem de um direito que favoreceu ao administrado, não cabe

88 GONÇALVES, Carlos Roberto. Direito civil brasileiro, volume 1: parte geral. 12. ed. São Paulo: Saraiva, 2014, p. 533.

89 EDUARDO, İtalo Romano, EDUARDO, Jeane Tavares Aragão. E-book. Curso de direito previdenciário. 12. ed. Rio de Janeiro: Forense; São Paulo: Método, 2016, p. 227.

90 VENOSA, Sílvio de Salvo. Direito civil, volume 1: parte geral. 15. ed. São Paulo: Atlas, 2015, p. 395. 
mais a anulação do ato que o causou, salvo se comprovada má-fé, conforme prescreve o por vezes aqui mencionado art. 54 da Lei $n^{0}$ 9.784/199991.

Assim, como o tribunal de contas é órgão independente, que não faz parte da Administração que proferiu o ato benéfico à parte, cabe agora a seguinte indagação: esse prazo quinquenal que consta do art. 54 da Lei n 9.784/1999 alcança o tribunal de contas em sua missão de controle externo?

Com o intuito de responder a essa pergunta, toma-se como parâmetro a apreciação por parte dos tribunais de contas da legalidade ato de aposentadoria, conforme dispõe a Constituição Federal.

Inicialmente, destaque-se que esse exame dos atos de aposentadoria refere-se somente àquelas concedidas no âmbito do serviço público e ligadas ao Regime Próprio de Previdência Social, posto que as aposentadorias outorgadas para os empregados celetistas não são apreciadas pelos tribunais de contas, haja vista que estão vinculadas ao Regime Geral de Previdência Social.

O ato de aposentadoria do servidor público, no entender do Supremo Tribunal Federal, é um ato complexo, posto que somente se aperfeiçoa com a sua apreciação pelo Tribunal de Contas, conforme se pode verificar do que consta do julgado nos autos do Agravo Regimental em Mandado de Segurança $n^{\circ}$ 35.483/DF ${ }^{92}$, cujo item 3 da ementa aproveita-se para transcrever, litteris:

3. O ato de aposentadoria de agentes públicos é complexo e somente se aperfeiçoa após o seu registro junto ao Tribunal de Contas da União. A partir desse momento é que começa a correr o prazo decadencial estabelecido pelo art. 54 da Lei 9.784/1999. Precedentes: MS 27.722 AgR, Rel. Min. Teori Zavascki, Segunda Turma, DJe 22/06/2016; MS 27.628 AgR, Rel. Min. Rosa Weber, Primeira Turma, DJe 06/11/2015; MS 28.604 AgR, Rel. Min. Marco Aurélio, Primeira Turma, DJe 21/02/2013; MS 25.697, Rel. Ministra Cármen Lúcia, Tribunal Pleno, DJe 12/03/2010.

Dessa forma, segundo extraído do próprio julgado acima, o art. 54 da Lei $n^{\circ}$ 9.784/99 somente se aplica ao Tribunal de Contas após este efetuar o referido registro do ato de aposentadoria.

91 BRASIL. LEI No 9.784 , de 20 de janeiro de 1999. Regula o processo administrativo no âmbito da Administração Pública Federal. Disponível em: <http://http://www.planalto.gov.br/ccivil 03/leis/L9784.htm>. Acesso em: 23 jul. 2018.

92 SUPREMO TRIBUNAL FEDERAL. Agravo Regimental em Mandado de Segurança ${ }^{\circ}$ 26.734/DF. Relator: LUIZ FUX. Pesquisa de Jurisprudência, Acórdãos, Brasília, 27 jun. 2018. Disponível em: $<$ http://www.stf.jus.br/portal/processo/verProcessoAndamento.asp?numero=35483\&classe=MS-

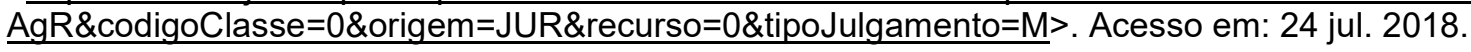


Ademais, por ser complexo, a apreciação pelos tribunais de contas da legalidade do ato inicial de concessão de aposentação do servidor público não necessita, em regra, passar pelo crivo do contraditório e da ampla defesa, conforme definido pela Súmula Vinculante $n^{\circ} 3$ do Supremo Tribunal Federal. ${ }^{93}$

Todavia, cabe destacar que, caso o processo de aposentadoria tenha sido enviado pelo órgão de origem ao tribunal de contas há mais de cinco anos, deverá ser concedida a ampla defesa e contraditório ao servidor aposentado, conforme pode ser observado do exposto nos autos do MS 24781/DF - STF. ${ }^{94}$

Relevante destacar também que, quando da apreciação do ato de aposentadoria, o respectivo tribunal de contas pode deparar-se com vantagens concedidas irregularmente ou sem amparo legal pela Administração, já percebidas pelo servidor há muitos anos ou até mesmo décadas.

Com bem leciona o professor Jorge Ulisses Jacoby Fernandes ${ }^{95}$, existem duas correntes que indicam como os tribunais de contas podem proceder diante de uma ilegalidade na apreciação do ato de concessão de aposentadoria, sendo que a primeira consiste em considerar toda a aposentadoria ilegal, quando for identificada a percepção de uma parcela indevida; a segunda, defende a legalidade do ato, todavia, a despesa que se originou da parcela indevida deve ser tida como ilegal.

Segue ainda o ilustre professor supra afirmando que, embora haja divergência de entendimento entre algumas cortes de contas, na esfera federal o juízo já foi pacificado, posto que existe norma própria, qual seja, a Instrução Normativa TCU $\mathrm{n}^{\circ} 16 / 97^{96}$, a qual permite considerar o ato legal e somente a parcela irregular como ilegal.

Independentemente de qual entendimento acima exposto seja adotado, é de se notar que o Tribunal de Contas, em sua missão de Controle Externo, examina a legalidade de determinada parcela, não se aplicando para ele o prazo

93 SUPREMO TRIBUNAL FEDERAL. Súmula Vinculante $\mathbf{n}^{\circ}$ 3. Brasília, 06 jun. 2007. Disponível em: $<$ http://www.stf.jus.br/portal/jurisprudencia/listarJurisprudencia.asp?s1=3.NUME.\%20E\%20S.FLSV \&base=baseSumulasVinculantes>. Acesso em: 25 jul. 2018.

94 SUPREMO TRIBUNAL FEDERAL. Mandado de Segurança $n^{\circ}$ 24781/DF. Relator: Ellen Gracie. Pesquisa de Jurisprudência, Acórdãos, Brasília, 09 jun. 2011. Disponível em: $<$ http://www.stf.jus.br/portal/jurisprudencia/listarJurisprudencia.asp?s1=\%2824781\%2ENUME\%2E + OU+24781\%2EACMS\%2E\%29\&base=baseAcordaos\&url=http://tinyurl.com/jz6o5v4>. Acesso em: 25 jul. 2018.

95 JACOBY FERNANDES, Jorge Ulisses. Tribunais de contas do Brasil: jurisdição e competência. 4. ed. Belo Horizonte: Fórum, 2016, p. 275.

96 Idem, p. 276. 
decadencial estabelecido no art. 54 da Lei $n^{\circ}$ 9.784/99, enquanto não for efetuado o registro do ato de aposentação.

Nesse momento, cabe registrar relevante situação fática que muitos gestores enfrentam na análise de processos administrativos que envolvem de algum modo a concessão de vantagens concedidas aos seus servidores, qual seja: ao identificar que o servidor recebe determinada vantagem ilegalmente, e passados mais de cinco anos do recebimento dessa parcela, caberia a Administração reformar a decisão que a concedeu, no intuito de extirpar a irregularidade e reduzir a remuneração do servidor?

A questão não é de fácil solução. Compulsando decisões dos Tribunais Superiores, verifica-se que por vezes o Poder Judiciário decidiu que o ato decisório que concedeu determinada vantagem ao servidor não pode mais ser revisto pela Administração, posto que estaria coberto pelo manto da decadência administrativa. A título exemplificativo, segue parte de ementa do Superior Tribunal de Justiça, que caminha nesse sentido, in verbis:

DIREITO ADMINISTRATIVO. PROCESSUAL CIVIL. AGRAVO REGIMENTAL NO AGRAVO DE INSTRUMENTO. ATO NULO. REVISÃO. DECADÊNCIA ADMINISTRATIVA. OCORRÊNCIA. FUNDAMENTO INATACADO EXISTENTE NO ACÓRDÃO ESTADUAL. INCIDÊNCIA DA SÚMULA 283/STF. ANTECIPAÇÃO DE TUTELA CONTRA A FAZENDA PÚBLICA. RESTAURAÇÃO DE SITUAÇÃO ANTERIOR. POSSIBILIDADE. HIPÓTESE NÃOPREVISTA NO ART. $1^{\circ}$ DA LEI 9.494/1997. PRECEDENTES DO STJ. INOVAÇÃO RECURSAL. IMPOSSIBILIDADE. DISSÍDIO JURISPRUDENCIAL NÃO-COMPROVADO. AGRAVO IMPROVIDO.

1. A vedação à concessão de tutela antecipada contra a Fazenda Pública, nos moldes do disposto no art. $1^{\circ}$ da Lei 9.494/97, não se aplica à hipótese de restabelecimento de parcela remuneratória ilegalmente suprimida, como na espécie. Precedente do STJ.

2. O prazo decadencial previsto no art. 54 da Lei 9.784/99 impõe-se como óbice à autotutela administrativa tanto nos atos nulos quanto nos anuláveis. Precedente do STJ97.

No entanto, defende-se agora no presente trabalho a possibilidade de a Administração afastar o prazo decadencial do art. 54 da Lei n 9.784/99, para assim modificar ou extirpar determinada parcela percebida ilegalmente pelo servidor, no que

97 SUPERIOR TRIBUNAL DE JUSTIÇA. Agravo Regimental no Agravo de Instrumento $\mathbf{n}^{\circ}$ 1127574/RS. Relator: ARNALDO ESTEVES LIMA. Pesquisa de Jurisprudência, Acórdãos, Brasília, 14 set 2009. Disponível em: <http://www.stj.jus.br/SCON/jurisprudencia/toc.jsp?processo$=1127574 \& \& b=A C O R \&$ thesaurus=JURIDICO\&p=true $>$. Acesso em: 28 jul. 2018. 
diz respeito aos atos decisórios cuja legalidade será mais tarde examinada no processo de aposentadoria pelo tribunal de contas.

Isso porque acastela-se aqui que o ato decisório concessor de direito à determinada vantagem ao servidor é inicialmente precário, posto que somente se aperfeiçoa após ser apreciado pelo tribunal de contas, quando da futura análise do processo de aposentadoria, capaz então de produzir a chamada coisa julgada administrativa.

Adotar postura distinta promove a situação jurídica esdrúxula de permitir que o servidor público receba determinada parcela irregular por vários anos ou até mesmo décadas, sob o manto da pretensa decadência administrativa, sendo que tal ato somente seria indicado para a sua correção quando da análise do processo de aposentação pelo tribunal de contas, o que permite concluir facilmente pela flagrante transgressão ao princípio do interesse público.

Ainda não há jurisprudência firme nesse sentido. Contudo existe precedente do STJ que permite modificar a averbação de tempo de serviço, para fins de abono de permanência, concedido pela Administração há mais de cinco anos da pretensa correção, pelo fato de que o abono de permanência só pode ser concedido ao servidor que venha a preencher os requisitos para a aposentação, que futuramente será analisada pelo tribunal de contas em processo de aposentadoria. Segue transcrição de parte da ementa desse julgado, constante dos autos do REsp $n^{\circ}$ 1.277.616 98 a seguir, litteris:

EMENTA ADMINISTRATIVO. ABONO DE PERMANENNCIA.
CANCELAMENTO. DESCONSIDERAÇÃO DA AVERBAÇÃO DO
TEMPO DE SERVIÇO RURAL. PRAZO DECADENCIAL. ATO
COMPLEXO. 1. A controvérsia discutida nos presente autos cinge-se
ao prazo decadencial para cancelamento do abono de permanência
de serviço em virtude da desconsideração da averbação de tempo de
serviço rural por ausência de recolhimento das contribuições
previdenciárias. 2 . O abono de permanência, instituído pela Emenda
Constitucional n. $41 / 2003$, é o reembolso da contribuição
previdenciária, devido ao servidor público que, já tendo cumprido
todas as exigências legais para se aposentar, decide permanecer em
atividade. Assim, para a sua concessão, impõe-se ao servidor público
implementar todas as condições para aposentadoria voluntária. 3 .
Considerando que a concessão de aposentadoria, nos termos da
jurisprudência majoritária desta Corte e do Supremo Tribunal Federal,

98 SUPREMO TRIBUNAL FEDERAL. Recurso Especial $\mathbf{n}^{\circ}$ 1.277.616/PR. Relator: MAURO CAMPBELL MARQUES. Pesquisa de Jurisprudência, Acórdãos, Brasília, 14 fev. 2012. Disponível em: $<$ http://www.sti.jus.br/SCON/jurisprudencia/toc.jsp?processo=1277616\&\&b=ACOR\&thesaurus=JURIDICO\&p=true>. Acesso em: 01 ago. 2018. 
é ato complexo que somente se completa após o registro no Tribunal de Contas da União, também o abono de permanência, que, como dito, depende do preenchimento de todos os requisitos para a aposentadoria, somente se aperfeiçoa após o exame da legitimidade de sua concessão pelo Tribunal de Contas por ocasião do registro do futuro ato de aposentadoria do servidor. Somente a partir dessa manifestação da Corte de Contas, terá início a fluência do prazo decadencial de 5 (cinco) anos previsto no art. 54 da Lei 9.784/99, para que a Administração Pública reveja o ato. 4. Recurso especial provido.

Isso posto, propõe-se que o gestor público, ao identificar uma vantagem percebida ilegalmente, que já venha sendo paga pela Administração além do prazo decadencial de 5 anos, promova a correção do ato decisório, desde que essa parcela seja ainda passível de análise futura pelo tribunal de contas quando do exame dos autos de aposentadoria, considerando que, por se tratar de ato complexo, aquela decisão ilegal que concedeu a vantagem é precária, e somente se aperfeiçoará após o exame da legalidade efetuado pela respectiva Corte de Contas, quando então, a partir daí, dar-se-á a contagem do prazo decadencial.

Cabe também lembrar que, embora defenda-se aqui a possibilidade de correção dessa vantagem ilícita, estritamente ligada ao direito, a cobrança dos valores recebidos indevidamente deverá respeitar o respectivo prazo prescricional, conforme já trabalhado em outro capítulo desse trabalho. Assim, somente poderão ser cobradas do servidor as parcelas irregulares que ainda não estejam prescritas.

Por fim, é de bom alvitre registrar que a devolução de quantias percebidas indevidamente pelo servidor pode ser até mesmo dispensada em algumas situações, caso este tenha percebido a vantagem de boa-fé e o pagamento tenha decorrido de erro escusável de interpretação de lei, realizada pelo órgão ou entidade ou pela autoridade responsável, conforme indica a Súmula $n^{\circ} 249$ do TCU. ${ }^{99}$

99 TRIBUNAL DE CONTAS DA UNIÃO. Súmula $\mathbf{n}^{\circ}$ 249. Relator: GUILHERME PALMEIRA. Pesquisa de Jurisprudência, Súmulas, Brasília, 09 mai. 2007. Disponível em: <2018.https://contas.tcu.gov.br/pesquisaJurisprudencia/\#/detalhamento/13/\%252a/NUMERO\%253A249\%2520 TIPONORMATIVO\%253A\%2522S\%25C3\%25BAmula\%2522/DTRELEVANCIA\%2520desc/false/1 Ifalse>. Acesso em: 01 ago. 2018. 


\section{CONCLUSÃO}

A exposição do presente trabalho monográfico teve como ponto de partida problema prático que muitos gestores administrativos enfrentam diariamente, que consiste na possibilidade ou não de se modificar uma decisão administrativa, considerando o efeito do lapso temporal bem como do controle externo dos tribunais de contas.

É bastante corriqueiro para o administrador da coisa pública ser alvo de pedidos de administrados que, por muitas vezes, não podem mais ser atendidos, posto que o largo caminhar do tempo já extinguiu o direito ou a pretensão do interessado.

Ademais, não raras as vezes também o gestor público identifica a percepção de alguma vantagem por parte do servidor público, concedida há muitos anos ilicitamente ou com erro de interpretação, surgindo então a dificuldade de concluir juridicamente se é possível ou não extinguir essa parcela, bem como de reaver os valores pagos indevidamente.

Inicialmente, o trabalho conceituou e destacou a importância do princípio da segurança jurídica, responsável por estabilizar as diversas formas de relações e, consequentemente, garantir a paz social. Em contraponto, discorreu-se sobre outro relevante princípio, que consiste na supremacia do interesse público, por meio do qual a Administração se coloca em posição de decidir buscando a melhor solução para toda a coletividade.

Após, foram abordados os institutos mais relevantes correlacionados com a implicação do tempo nas decisões administrativas, quais sejam: a preclusão administrativa, a prescrição e, por fim, a decadência.

Considerando o aspecto processual, destacou-se a importância da preclusão administrativa, posto que ela impede o devido caminhar do processo, em face da falta de alguma providência que deveria ter sido tomada tempestivamente pela parte interessada dentro dos autos, tornando a decisão administrativa imutável, em regra.

Como exemplo da relevância desse instituto, citou-se a perda de um prazo recursal, que então conduzirá a essa preclusão administrativa, e, 
consequentemente, finalizará os atos processuais, tornando a decisão não mais modificável no âmbito da Administração.

Todavia, no que tange ainda sobre a preclusão, importante destacar a defesa que se faz nessa monografia, no sentido de ser possível em alguns casos relevar a preclusão administrativa, em nome dos princípios do interesse público, da verdade real, do formalismo mitigado e da autotutela administrativa, a exemplo de recursos interpostos intempestivamente pela parte interessada, posto que deixar de conhecê-los poderia gerar reflexos danosos não só aos administrados, mas como também para a Administração.

Em ato subsequente, passou-se a discorrer sobre a prescrição, instituto de direito material intrinsicamente ligado ao princípio da segurança jurídica.

Isso porque, contemporaneamente, entende-se que a prescrição se configura após o advir de determinado prazo legal, que extingue pretensão específica, originada de uma violação de um direito, e, mais uma vez, com o principal objetivo de estabilizar as relações jurídicas, evitando surpresas indesejáveis para as partes.

Inicialmente, no que diz respeito à prescrição, necessário se fez buscar socorro nas normas e doutrinas civilistas, para só então chegar ao conceito supramencionado, posto que por vezes a definição de prescrição e de decadência não é bem delineada, e até mesmo é embaralhada nas normas que versam sobre o direito material, no âmbito do Direito Administrativo.

A preocupação em proteger a prescrição administrativa foi de tal ordem que o legislador infraconstitucional prescreveu no art. 112 da Lei $n^{\circ}$ 8.112/90 que a prescrição é de ordem pública, não podendo ser relevada.

Quanto ao instituto da decadência, com enfoque no âmbito administrativo, buscou-se descortiná-lo ao apresentar dispositivos das principais normas que versam sobre o assunto, dentre eles o celebrado art. 54 da Lei $n^{\circ}$ $9.784 / 1999$, além de ter sido exposta robusta doutrina sobre o tema.

A decadência administrativa, distintamente do que acontece com a prescrição, fulmina o próprio direito, e, por isso, levantou-se nesse trabalho a importante relação entre esse instituto e a impossibilidade de se anular um ato administrativo, dado o transcurso do respectivo prazo decadencial.

Frise-se que, em alguns casos, o prazo decadencial para que a Administração anule atos administrativos que conferiram efeitos favoráveis aos administrados pode ser afastado, em nome do interesse público. 
Nesse sentido, a parte final do art. 54 da Lei no 9.784/1999 contém licença para que o prazo decadencial de cinco anos seja desprezado pela Administração, quando se estiver diante de um ato praticado pelo administrado com má-fé.

Ressalte-se a existência de críticas severas na doutrina quanto à parte final desse dispositivo, sob o argumento de ser temerária uma decisão que a qualquer tempo pudesse vir a ser anulada pelo gestor público, considerando assim o contexto de crível transgressão ao princípio da segurança jurídica.

Ao final, passou-se a tratar sobre o tema central dessa monografia, que corresponde à relação entre o efeito estabilizador nas decisões administrativas do longo passar do tempo, considerando o controle externo realizado pelos tribunais de contas brasileiros.

A decadência administrativa, prescrita para a administração federal no art. 54 da Lei $n^{\circ} 9.784 / 99$, somente se aplica aos tribunais de contas após o registro do ato de aposentação, quando estes estão no exercício de sua missão constitucional de análise do ato complexo de aposentadoria, conforme entendimento do Supremo Tribunal Federal.

Dessa forma, quando os tribunais de contas analisam o ato complexo de aposentadoria, eles podem determinar a supressão de vantagens dos proventos dos servidores, recebidas por eles de forma irregular ou sem autorização legal, mesmo que já tenham se passado mais de cinco anos da decisão administrativa que conferiu a respectiva vantagem.

Por tudo exposto, finaliza-se o presente trabalho, propondo ao gestor administrativo que, ao identificar uma parcela indevidamente recebida por algum servidor, mesmo que da data da decisão que concedeu tal vantagem já tenha transcorrido o prazo quinquenal decadencial, essa vantagem seja extirpada do contracheque do agente público, posto que a decisão que a concedeu somente vai se aperfeiçoar no futuro, após o registro do ato de aposentadoria por parte dos tribunais de contas. 


\section{REFERÊNCIAS}

ALVIM, José Eduardo Carreira. E-book. Teoria geral do processo. 19. ed. rev., atual. e ampl. Rio de Janeiro: Forense, 2016.

BACELLAR FILHO, Romeu Felipe, MARTINS, Ricardo Marcondes. Ato administrativo e procedimento administrativo. São Paulo: Revista dos Tribunais, 2014.

BANDEIRA DE MELLO, Celso Antônio. Curso de direito administrativo. São Paulo: Malheiros, 2007.

BRASIL. CONSTITUIÇÃO FEDERAL, de 5 de outubro de 1988. Constituição da República Federativa do Brasil. Disponível em: <http://www.planalto.gov.br/ccivil 03/-constituicao/constituicaocompilado.htm>. Acesso em: 17 dez. 2017.

. DECRETO-LEI N²0.912, de 6 de janeiro de 1932. Regula a prescrição quinquenal. Disponível em:<http://www.planalto.gov.br/ccivil 03/decreto/Antigos/D20910.htm>. Acesso em: 04 fev. 2018.

DECRETO-LEI No 4.657, de 4 de setembro de 1942. Lei de Introdução às normas do direito brasileiro. Disponível em: <http://www.planalto.gov.br/ccivil 03/decreto-lei/Del4657compilado.htm>. Acesso em: 22 dez. 2017.

. LEI No 9.784, de 20 de janeiro de 1999. Regula o processo administrativo no âmbito da Administração Pública Federal. Disponível em: <http://www.planalto.gov.br/ccivil 03/leis/-L9784.htm>. Acesso em: 28 jan. 2018.

. LEI No 10.406, de 10 de janeiro de 2002. Código civil. Disponível em: $<$ http://www.planalto.gov.br/ccivil 03/leis/2002/L10406.htm>. Acesso em: 03 jan. 2018.

. LEI N $\mathrm{N}^{0} 13.105$, de 16 de março de 2015. Código de processo civil. Disponível em: <http://www.planalto.gov.br/ccivil 03/ ato20152018/2015/lei/113105.htm>. Acesso em: 27 dez. 2017.

. LEI No 8.112, de 11 de dezembro de 1990. Dispõe sobre o regime jurídico dos servidores públicos civis da União, das autarquias e das fundações públicas federais. Disponível em: <http://www.planalto.gov.br/ccivil 03/leis/L8112cons.htm>. Acesso em: 30 dez. 2017

CÂMARA, Alexandre Freitas. O novo processo civil brasileiro. 2. ed. São Paulo: Atlas, 2016.

CARVALHO FILHO, José dos Santos. E-book. Manual de direito administrativo. 31. ed. São Paulo: Atlas, 2017. 
. E-book. Processo administrativo federal: comentários à lei $\mathrm{n}^{\circ}$ 9.784/1999, de 29.1.1999. 5. ed. rev., ampl. e atual. até 31.3.2013. São Paulo: Atlas, 2013.

DI PIETRO, Maria Sylvia Zanella. Direito administrativo. 28. ed. São Paulo: Atlas, 2015.

EDUARDO, Ítalo Romano, EDUARDO, Jeane Tavares Aragão. E-book. Curso de direito previdenciário. 12. ed. Rio de Janeiro: Forense; São Paulo: Método, 2016.

FARIAS, Cristiano Chaves de, NETTO, Felipe Braga, ROSENVALD, Nelson. Manual de direito civil: volume único. Salvador: JusPodivm, 2017.

FERRAZ, Sérgio, DALLARI, Adilson Abreu. Processo administrativo. 3. ed. São Paulo: Malheiros Editores, 2012.

GAGLIANO, Pablo Stolze, PAMPLONA FILHO, Rodolfo. E-book. Novo curso de direito civil v. 1: parte geral. 19. ed. São Paulo: Saraiva, 2017.

GASPARINI, Diógenes. Direito administrativo. 20. ed. rev. e atual. São Paulo: Saraiva, 2003.

GOIÁS. LEI No 13.800, de 18 de janeiro de 2001. Regula o processo administrativo no âmbito da Administração Pública do Estado de Goiás. Disponível em: <http://www.gabinete-civil.goias.gov.br/leis ordinarias/2001/lei 13800.htm>.

Acesso em: 30 dez. 2017.

GOMES, Fábio Bellote. E-book. Elementos de direito administrativo. 2. ed. São Paulo: Saraiva, 2012.

GONÇALVES, Carlos Roberto. Direito civil brasileiro, volume 1: parte geral. 12. ed. São Paulo: Saraiva, 2014.

JACOBY FERNANDES, Jorge Ulisses. Tribunais de contas do Brasil: jurisdição e competência. 4. ed. Belo Horizonte: Fórum, 2016.

LEAL, Rosemiro Pereira. (05/2014). Teoria geral do processo: primeiros estudos. 12. ed. rev. e atual. Rio de Janeiro: Forense, 2014. [Minha Biblioteca]. Retirado: $<$ https://integrada.minhabiblioteca.com.br/\#/books/978-85-309-5637-0/>.

MEIRELLES, Hely Lopes; ALEIXO, Délcio Balestero; BURLE FILHO, José Emmanuel. Direito administrativo brasileiro.41. ed. São Paulo: Malheiros Editores, 2014.

MELLO, Marcos Bernardes de. Teoria do fato jurídico: plano da existência. 20. ed. São Paulo: Saraiva, 2014.

MENDES, Gilmar Ferreira, BRANCO, Paulo Gustavo Gonet. E-book. Curso de direito constitucional. 12. ed. rev. e atual. São Paulo: Saraiva, 2017. 
NADER, Paulo. E-book. Curso de direito civil - vol. 1: parte geral. 10. ed. rev. e atual. Rio de Janeiro: Forense, 2016.

NASSAR, Elody. E-book. Prescrição na administração pública. 2. ed. rev. e atual. São Paulo: Saraiva, 2009.

NOHARA, Irene Patrícia, MARRARA, Thiago. E-book. Processo administrativo: lei n 9.784/99 comentada. São Paulo: Atlas, 2009.

REALE, Miguel. Filosofia do direito. 20. ed. São Paulo: Saraiva, 2002.

RIO DE JANEIRO. LEI N 5427, de 01 de abril de 2009. Estabelece normas sobre atos e processo administrativo no âmbito do Estado do Rio de Janeiro e dá outras providências. Disponível em: <http://www.alerj.ri.gov.br/>. Acesso em: 30 dez. 2017.

SÃO PAULO. LEI No 10.177, de 30 de dezembro de 1998. Regula o processo administrativo no âmbito da Administração Pública Estadual. Disponível em: <https://www.al.sp.gov.-br/norma/?id=7505>. Acesso em: 26 dez. 2017.

SUNDFELD, Carlos Ari et al. Processo administrativo: temas polêmicos da lei $\mathrm{n}^{\circ}$ 9.784/99. São Paulo: Atlas, 2011.

SUPERIOR TRIBUNAL DE JUSTIÇA. Agravo Interno no Recurso em Mandado de Segurança $n^{\circ}$ 2016/0121257-6. Relator: Mauro Campbell Marques. Pesquisa de Jurisprudência, Acórdãos, Brasília, 03 out. 2016. Disponível em: $<$ http://www.stj.jus.br/SCON/jurisprudencia/toc.jsp?livre $=\% 22$ coisa+julgada+admin istrativa\%22\&\&b=ACOR\&thesaurus=JURIDICO\&p=true>. Acesso em: 16 jul. 2018.

Agravo Regimental no Agravo de Instrumento $n^{\circ}$ 1127574/RS. Relator: ARNALDO ESTEVES LIMA. Pesquisa de Jurisprudência, Acórdãos, Brasília, 14 set 2009. Disponível em: <http://www.stj.jus.br/SCON/jurisprudencia/toc. .jsp?processo $=1127574 \& \& b=A C O R \&$ thesaurus $=J U R I D I C O \& p=t$ rue >. Acesso em: 28 jul. 2018.

Agravo Regimental no Agravo em Recurso Especial n 129.718 - PE. Relator: Olindo Menezes. Pesquisa de Jurisprudência, Acórdãos, Brasília, 10 nov. 2015. Disponível em: <http://www.stj.jus.br/SCON>. Acesso em: 03 fev. 2018.

Agravo Regimental no Mandado de Segurança $\mathrm{n}^{\circ} 7.897$ - DF. Relatora: Laurita Vaz. Pesquisa de Jurisprudência, Acórdãos, Brasília, 04 mar. 2002. Disponível em: <http://www.stj.jus.br/SCON/jurisprudencia/toc.jsp?livre$=\% 28 \% 22 \mathrm{LAURITA}+\mathrm{VAZ} \% 22 \% 29 \cdot \mathrm{min}$. \&processo $=7897 \& \& \mathrm{~b}=\mathrm{ACOR} \&$ thesaurus $=\mathrm{J}$ URIDICO\&p=true>. Acesso em: 02 jan. 2018.

Agravo Regimental nos Embargos de Declaração no Recurso em Mandado de Segurança $\mathbf{n}^{\circ}$ 2008/0286249-3. Relator: NEFI CORDEIRO. Pesquisa de Jurisprudência, Acórdãos, Brasília, 05 nov. 2015. Disponível em: $<$ http://www.stj.jus.br/SCON/jurisprudencia/toc.jsp?livre $=\% 22$ coisa+julgada+admin istrativa\%22\&\&b=ACOR\&thesaurus=JURIDICO\&p=true>. Acesso em: 18 jul. 2018. 
. Embargos de Declaração no Agravo Regimental nos Embargos de Divergência em Recurso Especial $n^{\circ}$ 2012/0069215-2. Relator: Reynaldo Soares da Fonseca. Pesquisa de Jurisprudência, Acórdãos, Brasília, 02 dez. 2016. Disponível em: <http://www.stj.jus.br/SCON/jurisprudencia/toc.jsp?livre=\%22coisa+julgada+administrativa\%22+e+fiscal\&\&b=ACOR\&thesaurus=JURIDICO\& p=true >. Acesso em: 16 jul. 2018.

. Mandado de Segurança $n^{\circ} 19.579$ - DF. Relator: Mauro Campbell Marques. Pesquisa de Jurisprudência, Acórdãos, Brasília, 06 nov. 2013. Disponível em: <http://www.sti.jus.br/SCON/jurisprudencia>. Acesso em: 04 fev. 2018.

Recurso Especial n $^{\circ} 1109357$ - RJ. Relatora: Nancy Andrighy. Pesquisa de Jurisprudência, Acórdãos, Brasília, 01 jul. 2010. Disponível em: $<$ http://www.sti.jus.br/SCON/jurisprudencia/toc.jsp?processo=1109357\&\&b=ACOR \&thesaurus=JURIDICO\&p=true> $>$. Acesso em: 28 jan. 2018.

. Recurso Especial no 1346271/RS. Relator: OG FERNANDES. Pesquisa de Jurisprudência, Acórdãos, Brasília, 26 fev. 2018. Disponível em: $<$ http://www.sti.jus.br/SCON/jurisprudencia/toc.jsp?livre $=\% 22$ administrativo $\% 22+e$ $+\% 22$ reformatio+inpejus $\% 22 \& \& b=A C O R \&$ thesaurus=JURIDICO\&p=true $>$. Acesso em: 17 jul. 2018.

SUPREMO TRIBUNAL FEDERAL. Agravo Regimental em Mandado de Segurança $n^{\circ}$ 26.734/DF. Relator: LUIZ FUX. Pesquisa de Jurisprudência, Acórdãos, Brasília, 27 jun. 2018. Disponível em: <http://www.stf.jus.br/portal/processo/verProcessoAndamento.asp?numero $=35483 \&$ classe $=M S A g R \&$ codigoClasse $=0$ \&origem $=J U R \&$ recurso=0\&tipoJulgamento=M>. Acesso em: 24 jul. 2018.

. Embargos de Declaração no Recurso Ordinário nº RMS 30576 ED/DF. Relator: Dias Toffoli. Pesquisa de Jurisprudência, Acórdãos, Brasília, 06 nov.2013. Disponível em: <http://www.stf.jus.br/portal/jurisprudencia>. Acesso em: $04 \mathrm{fev}$. 2018.

Mandado de Segurança $n^{\circ}$ 24781/DF. Relator: Ellen Gracie. Pesquisa de Jurisprudência, Acórdãos, Brasília, 09 jun. 2011. Disponível em: $<$ http://www.stf.jus.br/portal/jurisprudencia/listarJurisprudencia.asp?s1=\%2824781 \%2ENUME\%2E+OU+24781\%2EACMS\%2E\%29\&base=baseAcordaos\&url=http:// tinyurl.com/jz6o5v4>. Acesso em: 25 jul. 2018.

Recurso Especial $n^{\circ}$ 1.277.616/PR. Relator: MAURO CAMPBELL MARQUES. Pesquisa de Jurisprudência, Acórdãos, Brasília, 14 fev. 2012. Disponível em: <http://www.sti.jus.br/SCON/jurisprudencia/toc.jsp?processo$=1277616 \& \& b=A C O R \&$ thesaurus-=JURIDICO\&p=true $>$. Acesso em: 01 ago. 2018.

Súmula $\mathbf{n}^{\circ}$ 473. Brasília, 03 dez. 1969. Disponível em: $<$ http://www.stf.jus.br/portal/jurisprudencia/listarJurisprudencia.asp?s1=473.NUME .$\% 20$ NAO\%20S.FLSV.\&base=baseSumulas $>$. Acesso em: 17 jul. 2018. 
Súmula Vinculante $\mathbf{n}^{\circ}$ 3. Brasília, 06 jun. 2007. Disponível em: $<$ http://www.stf.jus.br/portal/jurisprudencia/listarJurisprudencia.asp?s1=3.NUME.\% 20E\%20S.FLSV.\&base=baseSumulasVinculantes>. Acesso em: 25 jul. 2018.

TARTUCE, Flávio. Manual de direito civil. 6. ed. rev., atual. e ampl. São Paulo: Método, 2016.

TRIBUNAL DE CONTAS DA UNIÃO. Súmula $n^{\circ}$ 249. Relator: GUILHERME PALMEIRA. Pesquisa de Jurisprudência, Súmulas, Brasília, 09 mai. 2007. Disponível em: <2018.https://contas.tcu.gov.br/pesquisaJurisprudencia/\#/detalhamento/13/\%252a/NUMERO $\% 253$ A249\%2520TIPONORMATIVO\%253A\% 2522S\%25C3\%25BAmula\%2522/DTRELEVANCIA\%2520desc/false/1/false>. Acesso em: 01 ago. 2018.

VENOSA, Sílvio de Salvo. Direito civil, volume 1: parte geral. 15. ed. São Paulo: Atlas, 2015. 